Supplement of Biogeosciences, 17, 5615-5638, 2020 https://doi.org/10.5194/bg-17-5615-2020-supplement (C) Author(s) 2020. This work is distributed under the Creative Commons Attribution 4.0 License.

(c) (1)

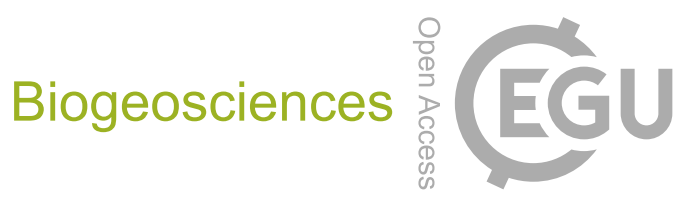

Supplement of

\title{
Global climate response to idealized deforestation in CMIP6 models
}

\section{Lena R. Boysen et al.}

Correspondence to: Lena R. Boysen (lena.boysen@mpimet.mpg.de)

The copyright of individual parts of the supplement might differ from the CC BY 4.0 License. 


\section{S1. Model description and specifications}

Table S1: Specifications of the participating models. $\Delta$ treeFrac refers to the tree fraction. piControl year refers to the branching year in which the deforest-globe simulation is started.

\begin{tabular}{|c|c|c|c|c|c|c|c|}
\hline Model name & $\begin{array}{l}\text { Land } \\
\text { model }\end{array}$ & $\begin{array}{l}\text { Spatial } \\
\text { resolution }\end{array}$ & $\begin{array}{l}\text { Num } \\
\text { ber of } \\
\text { realiz } \\
\text { ations }\end{array}$ & $\begin{array}{l}\text { Number of } \\
\text { years } \\
\text { simulated }\end{array}$ & $\begin{array}{l}\text { Dynamic } \\
\text { vegetation } \\
\text { module }\end{array}$ & Notes & Simulation DOI \\
\hline $\begin{array}{l}\text { MPI-ESM- } \\
\text { 1.2.0 }\end{array}$ & $\begin{array}{l}\text { JSBACH } \\
3.2\end{array}$ & $\begin{array}{l}192 \times 96 \\
\sim 1.9^{\circ} \times 1.9^{\circ}\end{array}$ & 7 & 150 & $\begin{array}{l}\text { Only in } \\
\text { piControl }\end{array}$ & piControl year 1899 & $\frac{\underline{\text { http://doi.org/10.2203 }}}{\underline{\text { 3/ESGF/CMIP6.6542 }}}$ \\
\hline $\begin{array}{l}\text { IPSL- } \\
\text { CM6A-LR }\end{array}$ & $\begin{array}{l}\text { ORCHI } \\
\text { DEE }\end{array}$ & $\begin{array}{l}144 \times 143 \\
2.5^{\circ} \times 1.27^{\circ}\end{array}$ & 3 & 80 & no & $\begin{array}{l}\text { Deforested grid cells } \\
\text { are selected on a area } \\
\text { (of forest) basis, not } \\
\text { on a fraction (of } \\
\text { forest) basis } \\
\text { piControl years } \\
1870,1910,1950\end{array}$ & $\frac{\text { http://doi.org/10.2203 }}{\underline{\text { 3/ESGF/CMIP6.5163 }}}$ \\
\hline CESM2 & CLM5 & $\begin{array}{l}288 \times 192 \\
1.25^{\circ} \times 0.94 \\
\circ\end{array}$ & 3 & 80 & $\begin{array}{l}\text { Only in } \\
\text { piControl }\end{array}$ & $\begin{array}{l}\Delta \text { treeFrac }=1929- \\
1850 \\
\text { cSoil }=\text { slow }+ \\
\text { medium + fast } \\
\text { piControl year } 501\end{array}$ & $\frac{\underline{\text { http://doi.org/10.2203 }}}{\underline{\text { 3/ESGF/CMIP6.7574 }}}$ \\
\hline $\begin{array}{l}\text { CNRM- } \\
\text { ESM2-1 }\end{array}$ & $\begin{array}{l}\text { ISBA- } \\
\text { CTRIP }\end{array}$ & $\begin{array}{l}256 \times 128 \\
\sim 1.4^{\circ} \times 1.4^{\circ}\end{array}$ & 1 & 80 & no & $\begin{array}{l}\text { cSoil }=\text { slow }+ \\
\text { medium }+ \text { fast } \\
\text { Separate file for } \\
\Delta \text { treeFrac } \\
\text { piControl year } 1850\end{array}$ & $\underline{\text { http://doi.org/10.2203 }}$ \\
\hline $\begin{array}{l}\text { BCC-CSM2- } \\
\text { MR }\end{array}$ & $\begin{array}{l}\text { BCC_A } \\
\text { VIM }\end{array}$ & $\begin{array}{l}320 \times 160 \\
\sim 1.125^{\circ} \times 1 \\
1^{\circ}\end{array}$ & 1 & 80 & no & $\begin{array}{l}\Delta \text { treeFrac }=1900- \\
1850 \\
\text { piControl year } 2289\end{array}$ & $\frac{\underline{\text { http://doi.org/10.2203 }}}{\underline{\text { 3/ESGF/CMIP6.2899 }}}$ \\
\hline CanESM5 & $\begin{array}{l}\text { CLASS3 } \\
.6 / \mathrm{CTE} \\
\mathrm{M} 1.2\end{array}$ & $\begin{array}{l}128 \times 64 \\
\sim 2.8^{\circ} \mathrm{x} \\
2.8^{\circ}\end{array}$ & 1 & 90 & no & piControl year 5700 & $\underline{\text { http://doi.org/10.2203 }}$ \\
\hline $\begin{array}{l}\text { UKESM1-0- } \\
\text { LL }\end{array}$ & $\begin{array}{l}\text { JULES- } \\
\text { ES-1.0 }\end{array}$ & $\begin{array}{l}192 \times 144 \\
1.87^{\circ} \times 1.25 \\
\circ\end{array}$ & 1 & 80 & $\begin{array}{l}\text { Both on } \\
\text { but off in } \\
\text { deforested } \\
\text { grid cell } \\
\text { fraction. }\end{array}$ & $\begin{array}{l}\Delta \text { treeFrac }=1900- \\
1850 \\
\text { piControl year } 1960\end{array}$ & $\underline{\underline{\text { http://doi.org/10.2203 }}}$ \\
\hline $\begin{array}{l}\text { MIROC- } \\
\text { ES2L }\end{array}$ & $\begin{array}{l}\text { Matsiro/ } \\
\text { VISIT }\end{array}$ & $\begin{array}{l}128 \times 64 \\
\sim 2.8^{\circ} \\
2.8^{\circ}\end{array} \quad \mathrm{x}$ & 1 & 150 & no & $\begin{array}{l}\text { No prescribing of } \\
\text { land cover types } \\
\text { possible (forest } \\
\text { regrowth); }\end{array}$ & $\underline{\underline{\text { http://10.22033/ESGF/ }}}$ \\
\hline
\end{tabular}




\begin{tabular}{|l|l|l|l|l|l|l|l|}
\hline & & & & & $\begin{array}{l}\text { separate file for } \\
\text { deforestation mask; } \\
\text { piControl year 1850 }\end{array}$ & \\
\hline $\begin{array}{l}\text { EC-Earth3- } \\
\text { Veg }\end{array}$ & $\begin{array}{l}\text { HTESSL } \\
\text { E/LPJ- } \\
\text { GUESS }\end{array}$ & $\begin{array}{l}512 \times 256 \\
\sim 0.7^{\circ} \times 0.7^{\circ}\end{array}$ & 1 & 80 & both & $\begin{array}{l}\text { Annual maximum of } \\
\Delta \text { treeFrac; separate } \\
\text { file for deforestation } \\
\text { mask; } \\
\text { cSoil slow }+ \\
\text { medium + fast } \\
\text { piControl year 1930 }\end{array}$ & $\underline{\text { 3/ESGF/CMIP6.4605 }}$ \\
\hline
\end{tabular}

\section{MPI-ESM-1.2.0:}

The Max-Planch Institute Earth System Model (MPI-ESM-1.2.0) couples the submodels of MPIOM1.6 for ocean physics, HAMOCC6 for ocean biogeochemistry, ECHAM6.3 for the atmosphere and JSBACH3.2 for the land surface (Mauritsen et al., 2019). JSBACH3.2 simulates eight natural plant functional types including tropical broadleaf evergreen and deciduous trees, extra-tropical evergreen and deciduous trees and $\mathrm{C} 3$ and $\mathrm{C} 4$ grasses. Following the protocol of simulating prescribed instead of dynamic vegetation, only net transitions between plant functional types occur. YASSO (Goll et al., 2015) simulates the decomposition of litter and soil carbon based on observed processes and data. YASSO distinguishes between above and below ground and woody as well as non-woody decomposition classes. The processbased SPITFIRE model (Lasslop et al., 2014) simulates burnt area depending on lightning and fire duration while the abundance, quality and moisture of fuel drive the spread rate. Trees are more resistant to fires compared to grasses and do not fully combust. Vegetation distribution is affected through mortality and nitrogen removal. The nitrogen cycle (Goll et al., 2017) is represented by using constant carbon-to-nitrogen ratios following the nitrogen demand. Nitrogen is added and removed through atmospheric deposition (biological fixation and denitrification) and leaching or fire, respectively. The hydrology scheme consists of five layers (Hagemann and Stacke, 2015) with prescribed soil depths, rooting depths, water holding capacities and soil textures.

\section{IPSL-CM6A-LR}

IPSL-CM6A-LR is the climate model developed by the Institut Pierre-Simon Laplace Climate Modelling Centre (IPSL CMC, see https://cmc.ipsl.fr) that participated in the CMIP6 exercise. It is composed of the LMDZ atmospheric model version 6A-LR, the NEMO oceanic model version 3.6 and the ORCHIDEE land surface model version 2.0 (Peylin, n.d.) Full description of the different components and the coupling can be found in Boucher et al. (submitted). The vegetation heterogeneity is represented by 15 Plant Functional Types ( 8 for trees, 4 for grasses, 2 for crops and 1 for bare soil). In the configuration used in CMIP6, vegetation distribution in each grid-cell is prescribed by land cover maps and only net land-use changes are considered. Three independent soil water columns are computed per grid cell, gathering some PFTs with similar properties together: one for bare soil, one for trees and another for short-vegetation types. On each water column, vertical water fluxes that account for hydraulic conductivity and diffusivity water are computed by a 11-layer soil hydrology scheme (de Rosnay et al., 2002) down to $2 \mathrm{~m}$ and a free drainage condition at the bottom of the soil column. In contrast to the water budget, a single energy budget is solved per grid cell. As a consequence, a single surface temperature is computed, with no possibility of 
distinguishing surface temperatures for the different PFTs covering a grid cell. Albedo values for soil, snow and vegetation for the different PFTs are set based on an optimization procedure using remote sensing albedo data from MODIS sensor. Regarding biomass modelling, carbon is the unique element represented in IPSL-CM6A-LR, nitrogen and other nutrient-related limitations being not considered. Governing equations defining the assimilation of carbon by photosynthesis and its flow within the plant-soil continuum are presented in (Krinner et al., 2005). Living biomass is represented by six main pools (leaf, fine roots, sapwood, heartwood in above and below grounds). Soil carbon biomass is modelled based on the CENTURY model (Parton et al., 1988) with three pools of different decomposition time (active, slow and passive pools). Removal of carbon due to fire activity is not considered in IPSL-CM6A-LR.

\section{CESM2}

The Community Earth System Model version 2 (CESM2, Danabasoglu et al., 2020) couples the Community Atmosphere Model (CAM6), the Community Land Model (CLM5, Lawrence et al., 2019), the Parallel Ocean Program model (POP2), and the Community Ice Sheet Model (CICE5). Full model descriptions and the performance of each component are described in the above references and references therein and in additional manuscripts in the AGU Special Issue on CESM2. CLM5 is the latest version of CLM and includes many updates to biogeophysical and biogeochemical and land use processes relative to prior CLM versions including: updated parameterizations and structure for hydrology and snow (spatially explicit soil depth, dry surface layer, revised groundwater scheme, revised canopy interception and canopy snow processes, updated fresh snow density, simple firn model, and Model for Scale Adaptive River Transport); plant hydraulics and hydraulic redistribution; revised nitrogen cycling (flexible leaf stoichiometry, leaf $\mathrm{N}$ optimization for photosynthesis, carbon costs for plant nitrogen uptake);) global crop model with six crop types and time-evolving irrigated areas and fertilization rates; updated stomatal physiology; and new parameter estimates for many key parameters. In CLM5, vegetation distributions are prescribed according to MODIS and the land use transitions from the Land Use Harmonization dataset (LUH2, Hurtt et al., 2020) CLM5 represents 14 natural plant functional types (PFTs) and 6 crop functional types. The vegetation state (LAI, phenology, canopy height) is prognostic in the biogeochemistry configuration used in default CESM2. This configuration includes full carbon and nitrogen cycling. PFTs on the naturally-vegetated land unit compete for water and nutrients.

Deforestation in the model is represented by contraction of tree PFT area within the natural vegetated land unit, as specified by a forcing dataset. In the idealized deforestation experiments, the tree PFTs are replaced by either $\mathrm{C} 3$ or $\mathrm{C} 4$ grass depending on dominant grass type at each location. Carbon from these trees is apportioned into several different streams including a direct carbon flux to the atmosphere, a transfer into wood product pools, and a transfer into slash (coarse woody debris and litter carbon pools) that is left on the soil column. CLM5 additionally represents deforestation fires in tropical closed forests (tropical tree PFTs $>60 \%$ coverage, Li et al. (2017) and references therein). Deforestation fires are defined as fires caused by deforestation, including escaped deforestation fires, termed degradation fires. Burned area of these fires is determined by the deforestation rate and climate conditions. 


\section{CanESM5}

CanESM5 (Swart et al., 2019) has evolved from its predecessor CanESM2 (Arora et al., 2011) that was used in the Coupled Model Intercomparison Project phase 5 (CMIP5). The major changes relative to CanESM2 are the implementation of completely new models for the ocean, sea-ice, marine ecosystems, and a new coupler. The resolution of CanESM5 (T63 or $\sim 2.8^{\circ}$ in the atmosphere and $\sim 1^{\circ}$ in the ocean) remains similar to CanESM2. The atmospheric component of CanESM5 has several improvements relative to its predecessor, including changes to aerosol, clouds, radiation, land surface and lake processes. Relative to the 35 levels used in CanESM2, CanESM5 uses 49 levels in the atmosphere and most of the additional 14 levels were added in the upper troposphere and stratosphere.

The land surface in CanESM5 is modelled using the Canadian Land Surface Scheme (CLASS) and the Canadian Terrestrial Ecosystem Model (CTEM) that together form the land component of CanESM5. CLASS and CTEM simulate the physical and biogeochemical land surface processes, respectively, and together they calculate fluxes of energy, water, $\mathrm{CO} 2$ and wetland $\mathrm{CH} 4$ emissions at the land-atmosphere boundary. Over land, three permeable soil layers are used with default thicknesses of $0.1,0.25$, and $3.75 \mathrm{~m}$ for which liquid and frozen soil moistures and temperature are prognostically calculated. The depth to bedrock is specified on the basis of the global data set which reduces thicknesses of the permeable soil layers where soil depth is less than 4.1 meters. In CLASS, snow is represented using one layer whose snow water equivalent and temperature are modelled prognostically. The introduction of dynamic wetlands and their methane emissions is a new biogeochemical process added since the CanESM2. CTEM simulates photosynthesis and prognostically calculates the amount of carbon in the model's three live (leaves, stem, and root) and two dead (litter and soil) carbon pools. Photosynthesis in CTEM is modelled at the same subdaily time as the physical processes. The remainder of the biogeochemical processes are modelled at a daily time step. These include, autotrophic and heterotrophic respirations, allocation of photosynthate from leaves to stem and roots, leaf phenology, turnover of live vegetation components that generates litter, mortality, and land use change. Nitrogen cycle over land is not represented but a parameterization of photosynthesis down-regulation as $\mathrm{CO} 2$ increases is included.

The physical ocean component of CanESM5 is based on NEMO version 3.4.1. It is configured on the tripolar ORCA1 C-grid with $45 \mathrm{z}$-coordinate vertical levels, varying in thickness from $\sim 6 \mathrm{~m}$ near the surface to $\sim 250 \mathrm{~m}$ in the abyssal ocean. The horizontal resolution is based on a $1^{\circ}$ Mercator grid, varying with the cosine of latitude, with a refinement of the meridional grid spacing to $1 / 3^{\circ}$ near the equator. Two modifications have been introduced to the NEMO's mesoscale and small-scale mixing physics in CanESM5 and these are detailed in Swart et al. (2019). Sea ice is represented using the LIM2 sea ice model, which is run within the NEMO framework. Ocean carbon cycle is represented using the Canadian Model of Ocean Carbon (CMOC) which was developed for earlier versions of CanESM (Arora et al., 2011; Christian et al., 2010), and includes carbon chemistry and biology. The biological component is a simple NutrientPhytoplankton-Zooplankton-Detritus (NPZD) model, with fixed Redfield stoichiometry, and simple parameterizations of iron limitation, nitrogen fixation, and export flux of calcium carbonate. 


\section{CNRM-ESM2-1:}

CNRM-ESM2-1 is the second generation Earth System model developed by CNRM-CERFACS for CMIP6 (Séférian et al., 2019). In CNRM-ESM2-1, ARPEGE-Climat_v6.3 forms the atmospheric core of the model (Roehrig, n.d.), coupled to the NEMOv3.6 ocean model incorporating the sea-ice model GELATOv6.0 and the ocean biogeochemistry model PISCES-v2-gas (Berthet et al., 2019). The land surface is represented by ISBA-CTRIP land surface model (Decharme et al., 2019; Delire et al., 2020).

The surface state variables and fluxes at the surface-atmosphere interface are simulated by the SURFEX modeling platform version 8.0 over the same grid and with the same time-step as the atmosphere model. SURFEXv8.0 encompasses several submodules for modeling the interactions between the atmosphere, the ocean, the lakes and the land surface. Over the land surface, CNRM-ESM2-1 use the ISBA-CTRIP land surface modeling system (http://www.umr-cnrm.fr/spip.php?article1092\&lang=en) to solve energy, carbon and water budgets at the land surface (Decharme et al., 2019; Delire et al., 2020). Its physical core explicitly solves the one-dimensional Fourier and Darcy laws throughout the soil, accounting for the hydraulic and thermal properties of soil organic carbon. It uses a 12-layer snow model of intermediate complexity that allows separate water and energy budgets for the soil and the snowpack. It accounts for a dynamic river flooding scheme in which floodplains interact with the soil and the atmosphere through free-water evaporation, infiltration and precipitation interception and a two-dimensional diffusive groundwater scheme to represent unconfined aquifers and upward capillarity fluxes into the superficial soil. More details on these physical aspects can be found in Decharme et al. (2019).

To simulate the land carbon cycle and vegetation-climate interactions, ISBA-CTRIP simulates plant physiology, carbon allocation and turnover, and carbon cycling through litter and soil. It includes a module for wild fires, land use and land cover changes, and carbon leaching through the soil and transport of dissolved organic carbon to the ocean. Leaf photosynthesis is represented by the semi-empirical model proposed by Goudriaan et al. (1985). Canopy level assimilation is calculated using a 10-layer radiative transfer scheme including direct and diffuse radiation. Vegetation in ISBA is represented by 4 carbon pools for grasses and crops (leaves, stem, roots and a non-structural carbohydrate storage pool) with 2 additional pools for trees (aboveground wood and coarse roots). Leaf phenology results directly from the carbon balance of the leaves. The model distinguishes 16 vegetation types (10 tree and shrub types, 3 grass types and 3 crop types) alongside desert, rocks and permanent snow. In the absence of nitrogen cycling within the vegetation, an implicit nitrogen limitation scheme that reduces specific leaf area with increasing $\mathrm{CO}_{2}$ concentration was implemented in ISBA following the meta-analysis of (Yin, 2002). Additionally, there is an ad-hoc representation of photosynthesis down-regulation. The litter and soil organic matter module is based on the soil carbon part of the CENTURY model (Parton et al., 1988). The 4 litter and 3 soil carbon pools are defined based on their location above- or below-ground and potential decomposition rates. The litter pools are supplied by the flux of dead biomass from each biomass reservoir (turnover). Decomposition of litter and soil carbon releases $\mathrm{CO}_{2}$ (heterotrophic respiration). During the decomposition process, some carbon is dissolved by water slowly percolating through the soil column. This dissolved organic carbon is transported by the rivers to the ocean. A detailed description of the terrestrial carbon cycle can be found in Delire et al. (2020). 


\section{BCC-CSM2-MR}

The land model in BCC_CSM is the Beijing Climate Center Atmosphere and Vegetation Interaction Model (BCC_AVIM, Li et al., 2019). It is a comprehensive land surface model and can be coupled into the BCC_CSM to simulate land surface biogeophysical and plant ecophysiological processes (Wu et al., 2013, 2019). There are exchanges of energy, water, and carbon between the land surface and the atmosphere. The terrestrial carbon cycle in BCC_AVIM operates through a series of biochemical and physiological processes on photosynthesis and respiration of vegetation. A dynamic determination of leaf unfolding, growth, and withering dates according to the budget of photosynthetic assimilated carbon similar to the phenology scheme was implemented in BCC_AVIM.

\section{MIROC-ES2L:}

This model is based on the global climate model MIROC5.2 (Tatebe et al., 2018), which interactively couples an atmospheric general circulation model (CCSR-NIES AGCM, Tatebe et al., 2019) including an on-line aerosol component (SPRINTARS, Takemura et al., 2000), an ocean GCM with sea-ice component (COCO, Hasumi, 2006), and a land physical surface model (MATSIRO, Takata et al., 2003). The land and ocean biogeochemical components are represented in MIROC-ES2L by VISIT(Ito and Inatomi, 2011) and OECO2. The two land components (MATSIRO and VISIT) are coupled via soil water content, runoff, and leaf area index (Arora et al., 2019; Hajima et al., 2020).

The model simulates the terrestrial carbon cycle, with vegetation (leaf, stem, and root), litter (leaf, stem, and root), and humus (active, intermediate, and passive) pools and with a fixed biome distribution (based on MODIS vegetation cover category). Details on carbon cycle processes in the model can be found in (Ito and Oikawa, 2002). Nitrogen cycle is also simulated with pools of vegetation (canopy and structural), organic soil (litter, humus, and microbe), and inorganic nitrogen (ammonium and nitrate). For installing into MIROC-ES2L, the terrestrial ecosystem processes were modified such that photosynthetic capacity is controlled by leaf $\mathrm{N}$ concentration (Arora et al., 2019; Hajima et al., 2020).

The LUC impact is modeled assuming two types of land use impact on the biogeochemistry. First, even when a simulation is conducted with fixed areal fractions (e.g., a spin-up run under 1850 conditions), crop harvesting, nitrogen fixation by $\mathrm{N}$-fixing crops, and the decay of organic matter in product pools occur. Second, when an areal fraction is changed within a year, carbon and nitrogen in the harvested biomass are translocated between product pools. When cropland is abandoned and the area is reclassified as secondary forest, the apparent mean mass density of secondary forest is first diluted because of the increase in the less-vegetated area, and then secondary forest starts regrowth toward a new stabilization state (Hajima et al., 2020).

\section{UKESM1-0-LL:}

UKESM1-0-LL is the low resolution version of the UK Earth System Model (Sellar et al., 2019). The Met Office Unified Model at vn11.2 forms the atmospheric core of the model, coupled to the NEMO ocean (vn3.6) incorporating version 2.0 of the MEDUSA ocean biogeochemistry model (Yool et al., 2013). The land surface is represented by vn5.0 of the JULES land surface model (Clark et al., 2011). JULES features 9 natural PFTs (three broadleaf trees, two needleleaf trees, two shrubs and two grasses (Harper et al., 2016) with an additional 4 devoted to agriculture (C3 and $\mathrm{C} 4$ crop and pasture, Robertson et al., submitted). The natural and agricultural PFTs form entirely separate units within the grid box; the dynamic vegetation 
model, TRIFFID, allows the PFTs within each unit to compete with each other for space in response to the evolving climate, but there is no competition between natural and agricultural PFTs. Dynamic vegetation must therefore be switched on to determine the PFT composition within each unit (natural / agricultural), but there is no possibility of natural trees and shrubs repopulating agricultural regions. The fraction of the grid box devoted to agriculture is prescribed, with the fractions in which crop PFTs and pasture PFTs are permitted to grow read in separately. As the fraction of the grid box devoted to agriculture grows, natural vegetation is cleared away, to be replaced with bare soil; the leaf, stem and coarse root carbon is added to three wood product pools which decay at different rates, leading to a land use change $\mathrm{CO} 2$ emissions flux; fine root carbon from cleared vegetation is added to the soil.

The soil carbon component of JULES is based on the RothC four-pool soil Carbon model (Coleman et al., 1997): the four soil carbon pools comprise Decomposable Plant Material (DPM), Resistant Plant Material (RPM), Biomass (BIO), and Humus (HUM), each with a representative decay rate. Plant litter is added to the DPM and RPM pools; carbon passes from these into the BIO and HUM pools where it continues to decay, with some carbon lost as $\mathrm{CO}_{2}$ at each stage. Version 5.0 of JULES includes nitrogen limitation of carbon uptake by plants; there are four organic soil nitrogen pools mirroring the four soil carbon pools, as well as an additional inorganic soil nitrogen pool. Associated with the photosynthetic carbon uptake by vegetation is a demand for nitrogen, calculated from the plants' C:N ratio and the Net Primary Productivity (NPP). The inorganic soil nitrogen pool is available to plants to meet this demand: if there is insufficient nitrogen in the inorganic pool to satisfy it, the plants' NPP is downregulated accordingly. The inorganic pool is replenished by biogenic nitrogen fixation as a function of NPP, and Nitrogen deposition from the atmosphere, which is prescribed. Crop PFTs are not nitrogen limited; they are assumed to be fertilized perfectly, insofar as their N demand is met, and NPP not downregulated, constituting an implicit nitrogen fertilization flux. A portion of crop litter is intercepted, representing a harvest flux. Pasture PFTs are neither fertilized, nor subject to any removal by harvest or grazing. When the model is configured to run in $\mathrm{CO}_{2}$ concentration-driven mode, the $\mathrm{CO}_{2}$ flux from the decay of the wood product pools, the harvest flux, and the NPP carbon not assimilated by the plants are all diagnostic-only, whereas when the model is in $\mathrm{CO}_{2}$ emissions-driven configuration, they combine to form a $\mathrm{CO}_{2}$ flux added directly to the atmosphere $\mathrm{CO}_{2}$ store.

\section{EC-Earth-Veg 3.3.1.1:}

EC-Earth-Veg v3.3.1.1 (Doescher et al., n.d.; Miller et al., n.d.; Wyser et al., 2019, 2020) a subconfiguration of the Consortium Earth-system model EC-Earth (Hazeleger et al., 2012) that incorporates the atmospheric model IFS cycle 36r4 including the Land-Surface model HTESSEL (e.g. Boussetta et al., 2013), the ocean model NEMO3.6 (Vancoppenolle et al., 2009) including the sea-ice model LIM3, and the process-based $2^{\text {nd }}$ generation dynamic global vegetation and biogeochemistry model LPJ-GUESSv4.0 (based on Lindeskog et al., 2013; Olin et al., 2015; Smith et al., 2014b). The coupling between the components is handled by the OASIS3-MCT coupling library (Craig et al., 2017). Here, the standard resolution has been applied (see Doescher, in prep.).

In this setup HTESSEL (biogeophysics and water-cycle) and LPJ-GUESS (dynamic vegetation and biogeochemistry) act as a combined land-surface scheme.

LPJ-GUESS simulates vegetation dynamics, management and land use, as well as the terrestrial $\mathrm{C}$ and $\mathrm{N}$ cycles on six different stand-types, of which five have dynamical grid cell fractions following LUH2 (Natural, Pasture, Urban, Crop, and Irrigated Crop) and one is fixed in gridcell-fraction (Peatland). On Natural stands ten woody and two herbaceous PFTs are in competition (Smith et al., 2014a), while on 
Urban, Pasture, and Peatland stands two herbaceous PFTs (according to the C3 and C4 photosynthesispathways) compete. There are five crop functional types in the cropland fraction that do not experience any competition from other PFTs. Dynamic vegetation, where cohorts of individual PFTs compete for space, light and soil resources (water, N) within each replicate patch is a fundamental part of LPJ-GUESS and cannot be switched off. Nonetheless, in the special deforest globe simulation described here tree establishment is disabled on the stand areas that are deforested, after which only the two herbaceous PFTs are in competition. The global $\mathrm{C}$ and $\mathrm{N}$ cycles are represented in vegetation, litter and soil organic matter (SOM) pools. C-N dynamics induces nutrient limitation on natural vegetation and crop growth, and decomposition rates of SOM that will influence soil biogeochemistry, $\mathrm{CO} 2$ fluxes and $\mathrm{N}$ trace gas emissions. In this version, the fire-model GlobFIRM (Thonicke et al., 2001) is used, providing fire-related $\mathrm{C}$ and $\mathrm{N}$ turnover and fluxes once per year.

In the EC-Earth3 setup LPJ-GUESS provides LAI and effective cover-fraction for the dominant high and low vegetation classes used by HTESSEL on a daily basis, affecting phenology. The dominant high and low vegetation types are determined at the end of each simulated year.

HTESSEL computes the energy and water balance for six potentially present surface tiles: bare-ground, low and high vegetation, water intercepted by vegetation, and snow both exposed and shaded by vegetation. Albedo, surface roughness, rooting depth and other parameters related to surface energy balance and turbulent heat exchange depend on vegetation type and cover and are determined from fixed values in IFS/HTESSEL look-up tables.

In this version, water cycling in LPJ-GUESS is decoupled from the rest of EC-Earth due to the different evaporation and hydrology schemes in HTESSEL and LPJ-GUESS. HTESSEL has a single soil water pool per gridcell, updated each sub-daily time-step based on the aggregated water fluxes to and from each tile. Evaporation and soil water uptake does not take photosynthesis into account. In contrast, carbon and water cycling is coupled in LPJ-GUESS (Peters et al., 2018; Smith et al., 2014a), such that evapotranspiration is calculated independent in each patch and stand in every gridcell. This reflects the sub-grid scale heterogeneity of hydrological cycling in each grid cell resulting from different ecosystem functioning in each land use class, as well as vegetation in various stages of succession in the patches that make up the Natural stands.

Deforestation has been implemented such that in an affected grid-cell every year a certain amount of Natural land as primary forest is converted to secondary forest on which tree establishment is disabled. The vegetation removal on the deforested stand area is implemented by our wood-harvest implementation, which does remove most of the vegetation within the deforested stand area, but a portion of leaves, wood, and roots are left on site and are transferred into the litter.

LPJ-GUESS has been evaluated in a multitude of studies, e.g. Peters et al. (2018); Piao et al. (2013); Sitch et al. (2015); Smith et al. (2014a); Zaehle et al., (2014). 


\section{S2. Supplementary figures}

(a) MPI-ESM-1.2.0

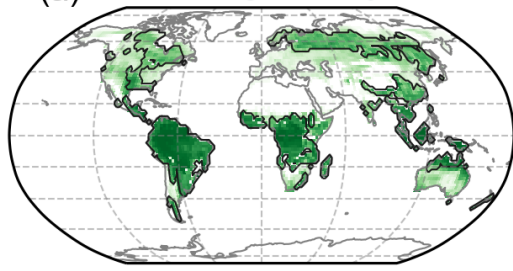

(d)

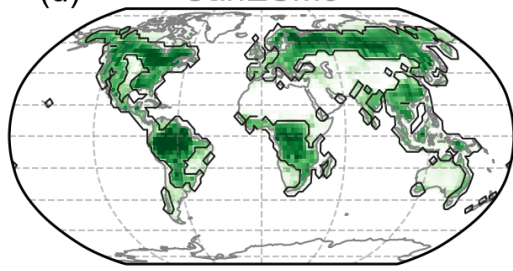

(g)

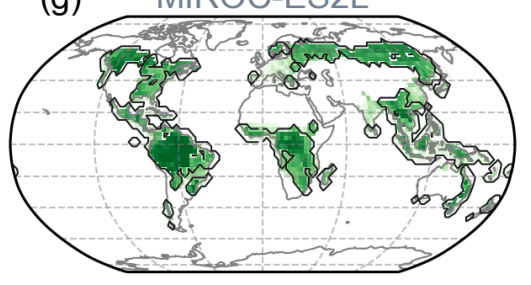

$\Delta \mathrm{F}$ (b) IPSL-CM6A-LR

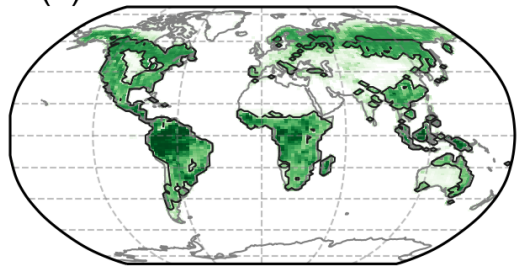

(e) CNRM-ESM2-1

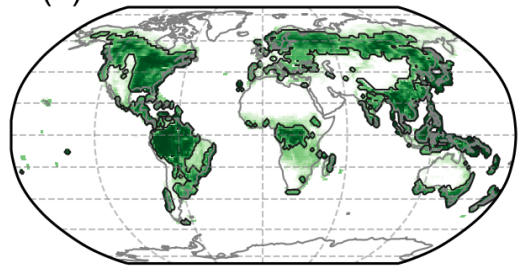

(h)

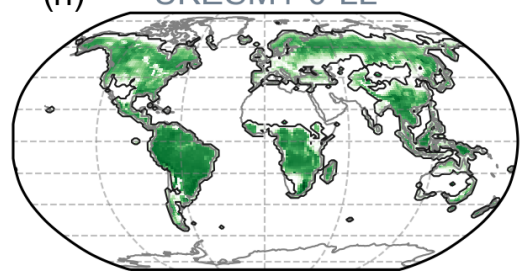

Initial Forest Fraction [\%]

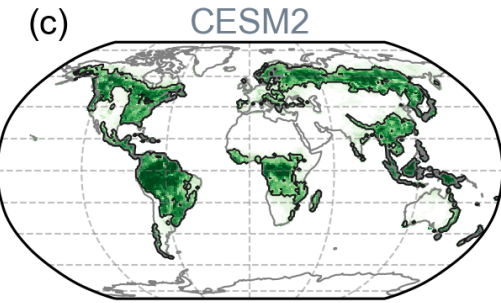

(f) BCC-CSM2-MR

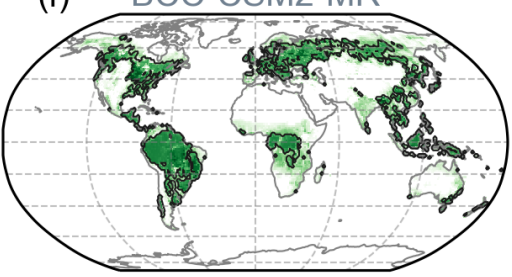

(i) EC-Earth3-Veg

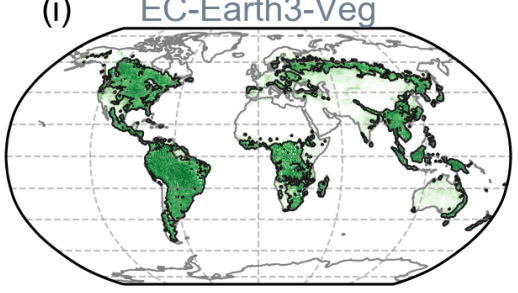

$80 \quad 90 \quad 100$

Fig. S1: Initial forest cover given in percent. Note that this is derived from the piControl simulation unless stated differently in section 3.1 of the manuscript or Table S1. 


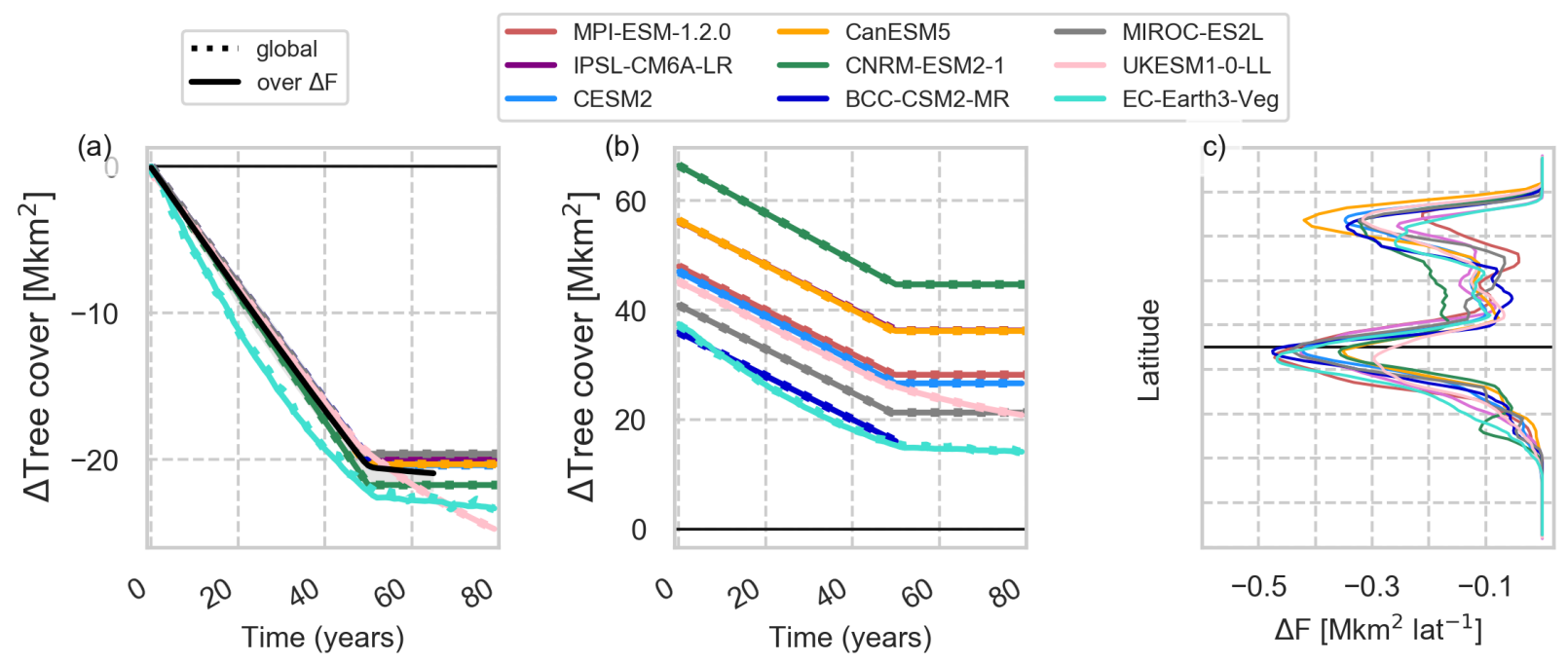

Fig. S2: Global deforestation extent in $\mathrm{Mkm}^{2}$ (a) relative to the initial forest cover extent and (b) starting from the initial forest extent; (c) shows the zonal deforestation pattern per latitude. 


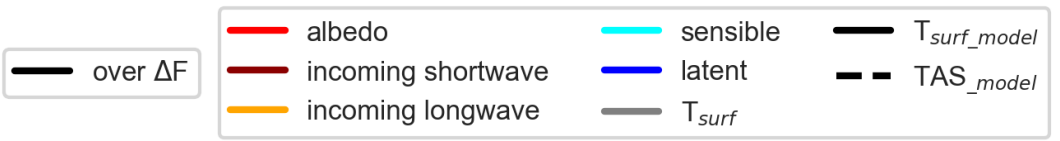

(a) MPI-ESM-1.2.0

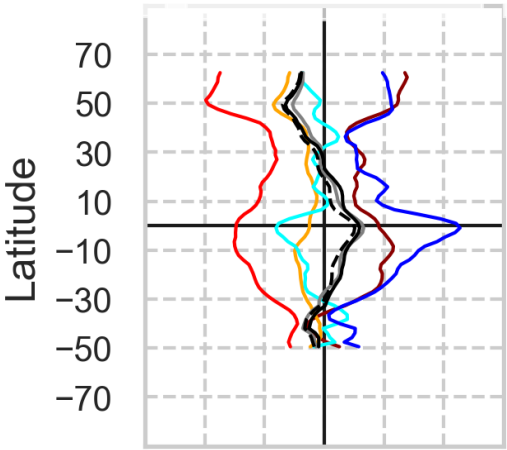

(d) CanESM5

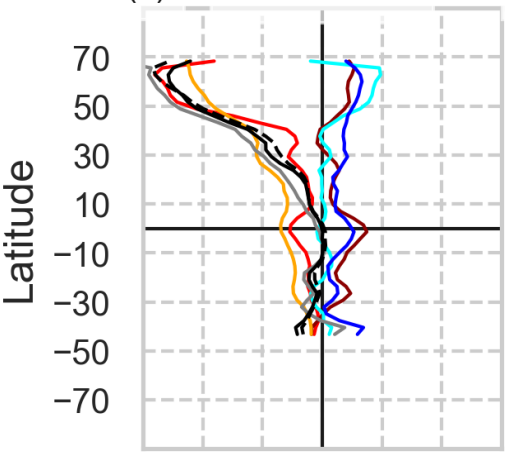

(g) MIROC-ES2L

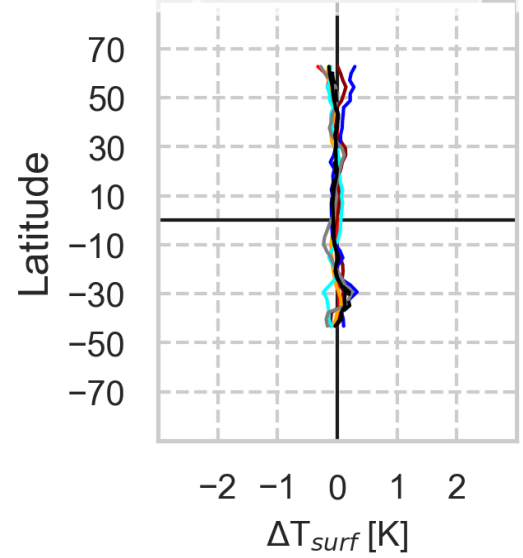

(b) IPSL-CM6A-LR

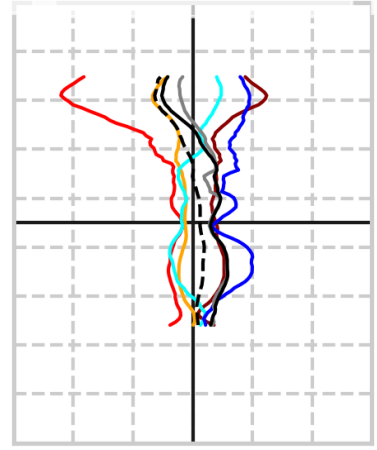

(e) CNRM-ESM2-1

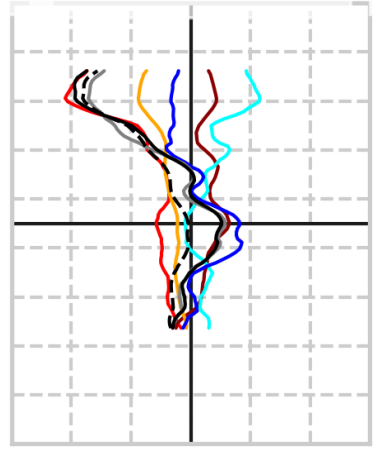

(h) UKESM1-0-LL

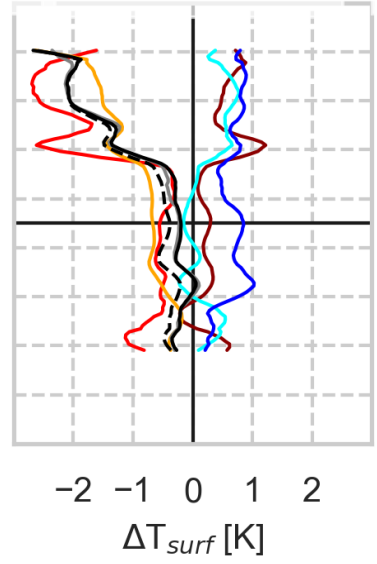

(c)

CESM2

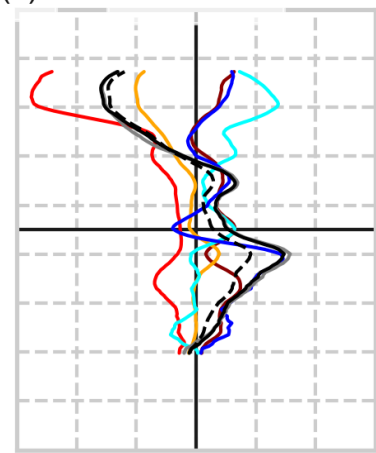

(f) BCC-CSM2-MR

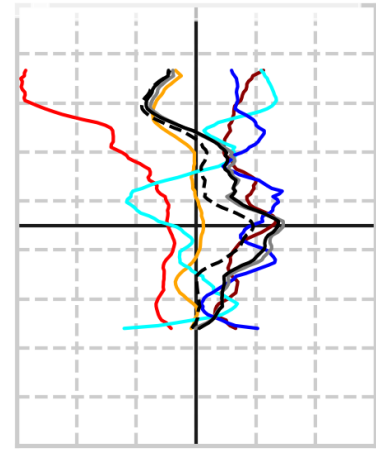

(i) EC-Earth3-Veg

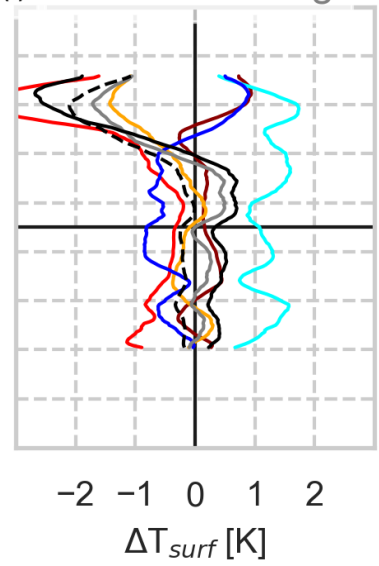

Fig. S3: Zonally averaged surface energy balance (SEB) components after deforestation (averaged over year 50 to year 79), expressed as contribution of changes in available energy (incoming and reflected shortwave and incoming longwave) and turbulent heat fluxes (latent and sensible) to changes in the surface temperature $\left(\mathrm{T}_{\text {surf }}\right)$. $\mathrm{T}_{\text {surf }}$ is derived from the SEB decomposition method; $\mathrm{T}_{\text {surf }}$ model as simulated by each model; The difference of $\mathrm{T}_{\text {surf model }}$ and $\mathrm{T}_{\text {surf }}$ represents the residual flux accounting for the ground heat flux and subsurface heat storage. For comparison, the simulated near-surface temperature ( $\Delta$ Tas) is shown as 
well. An approximated running mean over 10 degrees latitude was applied to smooth lines. Only changes over deforested grid cells are shown. 
$\longrightarrow$ over $\Delta F$

(a)

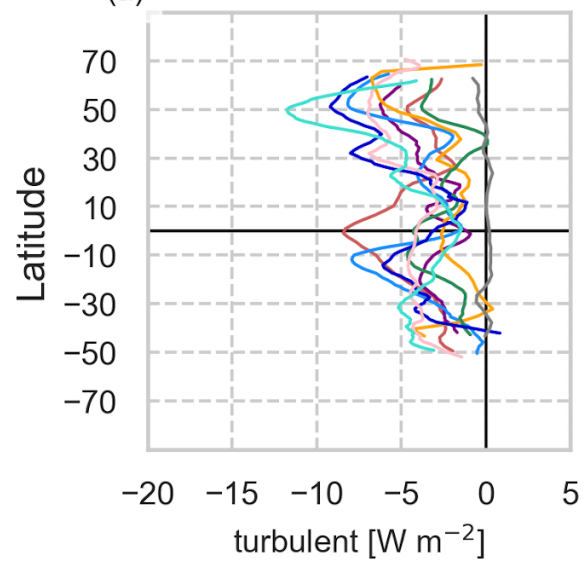

(d)

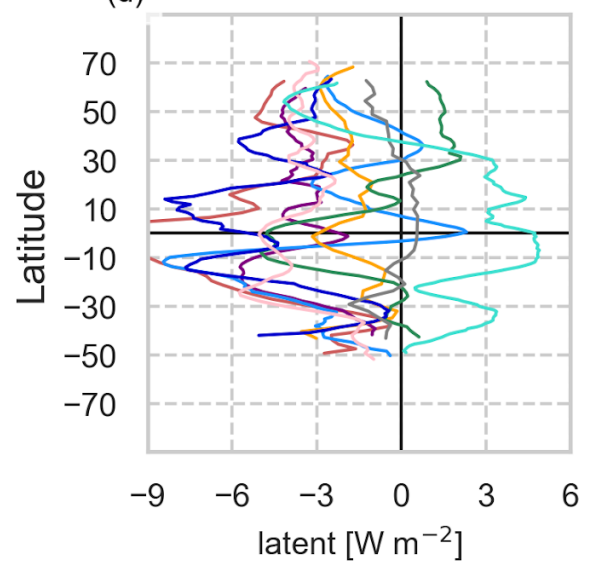

(g)

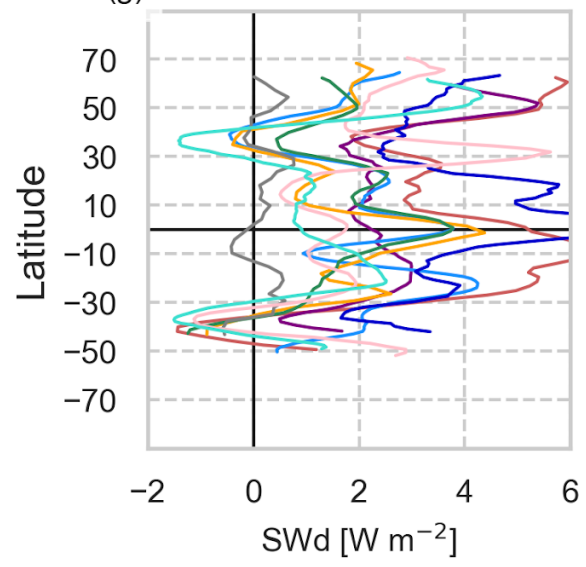

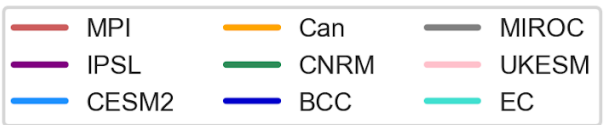

(b)

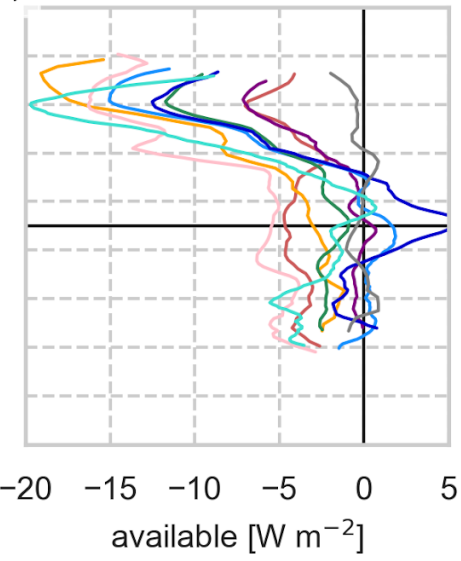

(c)

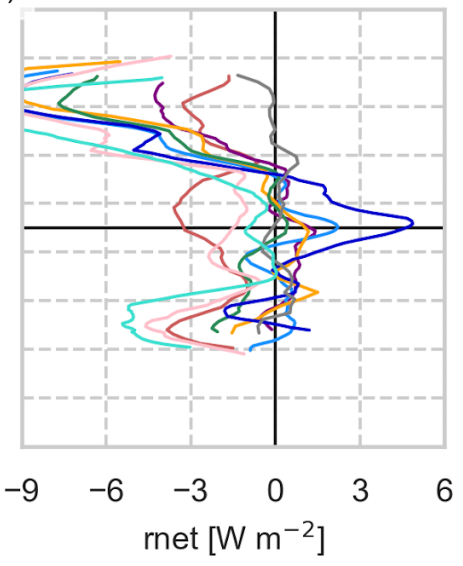

(e)

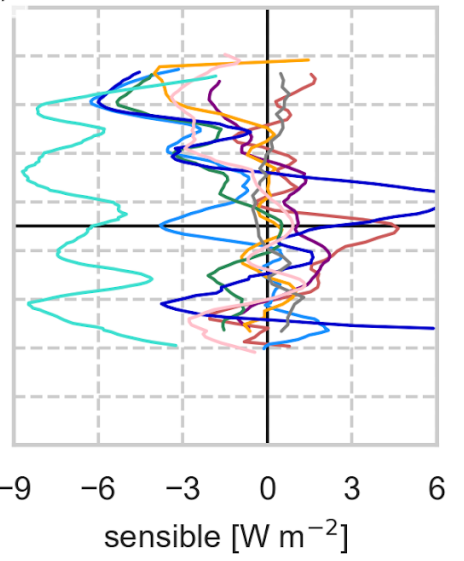

(f)

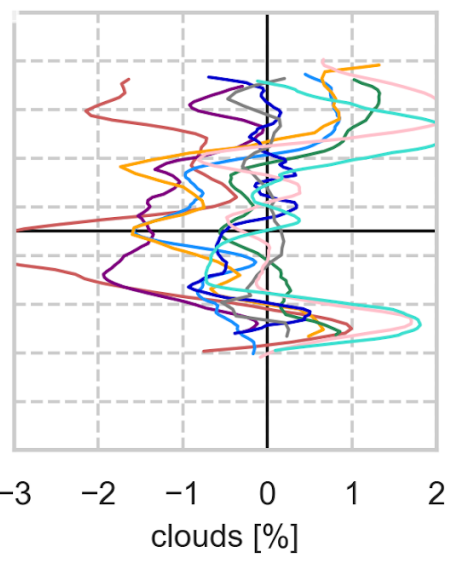

(h)

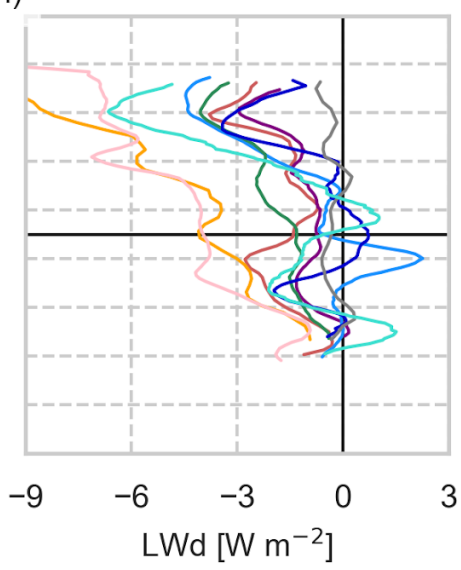

(i)

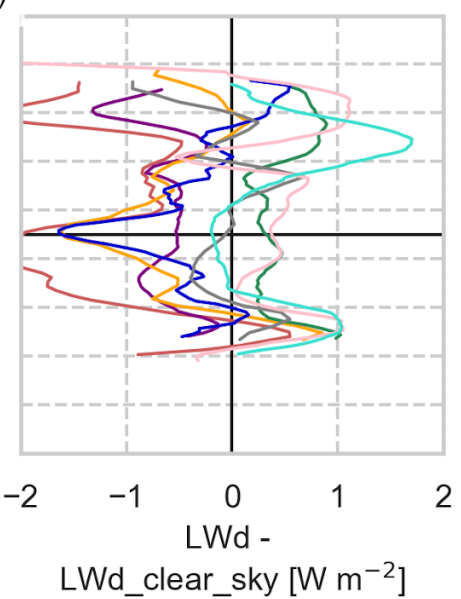

Fig. S4: Latitudinal means of surface energy fluxes (in $\mathrm{W} \mathrm{m}^{-2}$ ) and total cloud cover (in \%). (a) turbulent heat flux (sum of latent and sensible heat), (b) available energy (sum of net shortwave and downward 
longwave radiation, (c) net shortwave radiation, (d) and (e) latent and sensible heat flux, respectively, (f) total cloud cover (in percent), (g) and (h) display the downward shortwave and long wave radiation fluxes at the surface, respectively. Smoothing was achieved by applying a running mean of approximately 10 degrees.
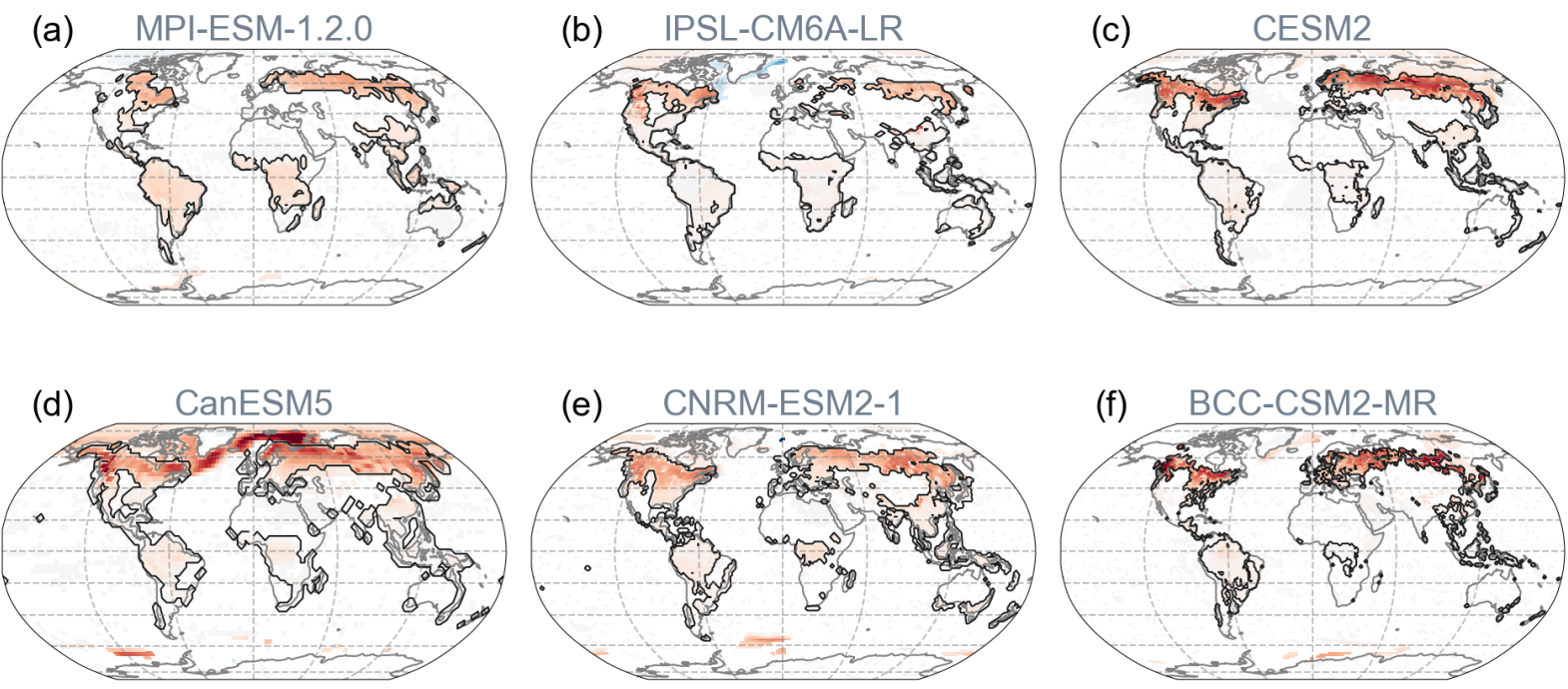

(e) CNRM-ESM2-1
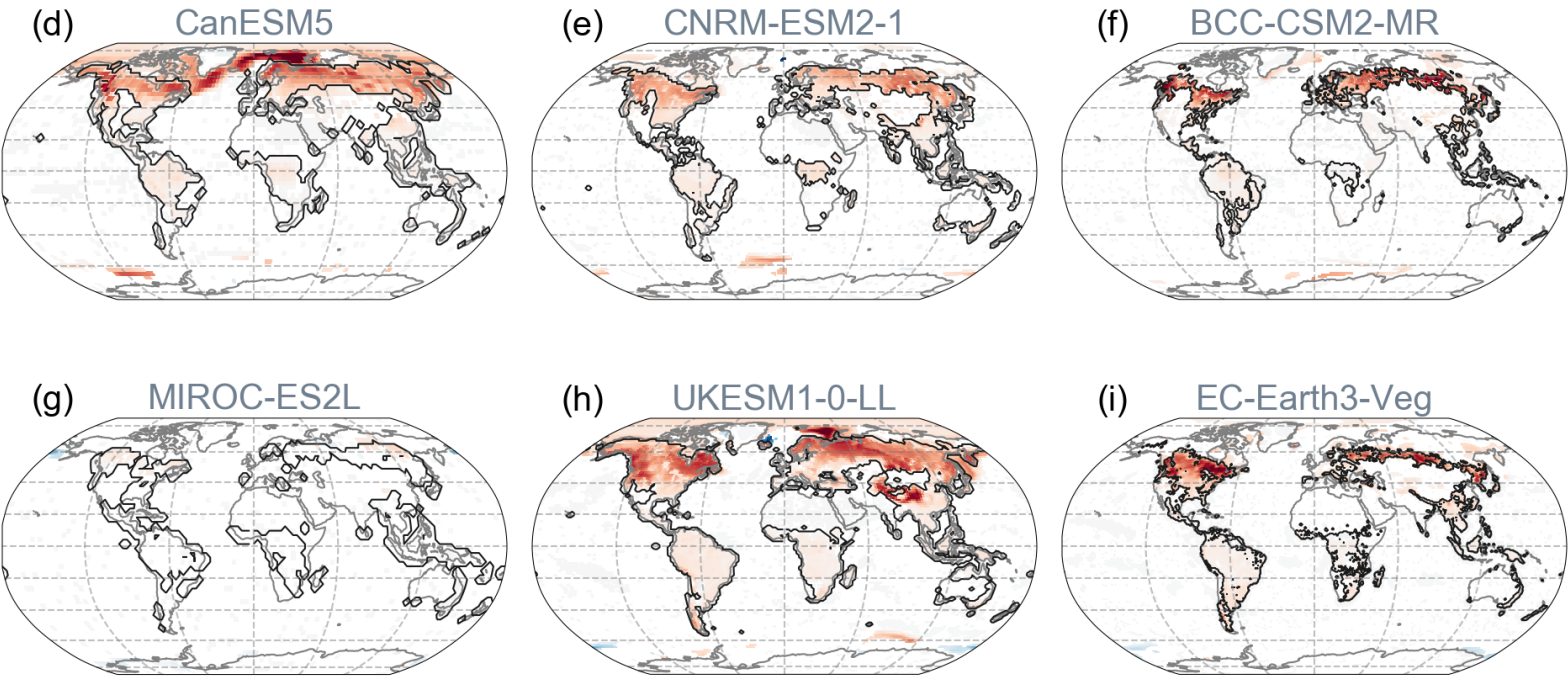

(h) UKESM1-0-LL
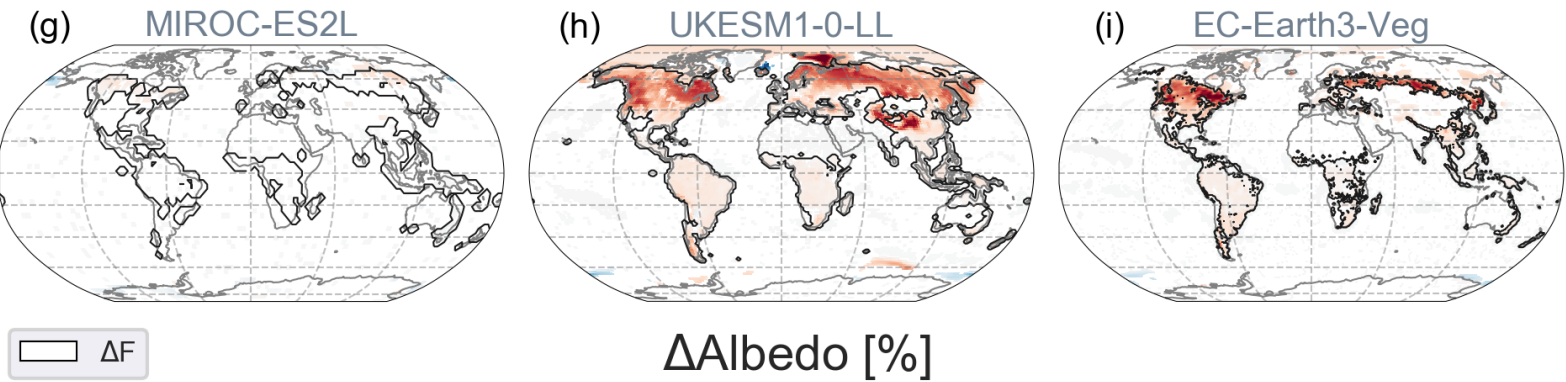

$\triangle$ Albedo [\%]

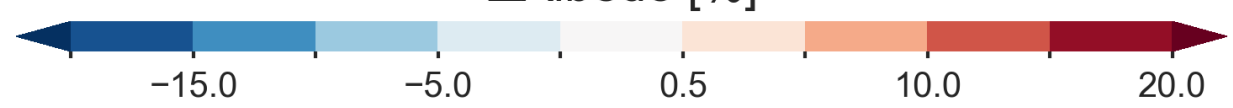

Fig. S5: Changes in albedo given in percent from (mean over years t80 - t51). Only statistically significant changes are shown. 

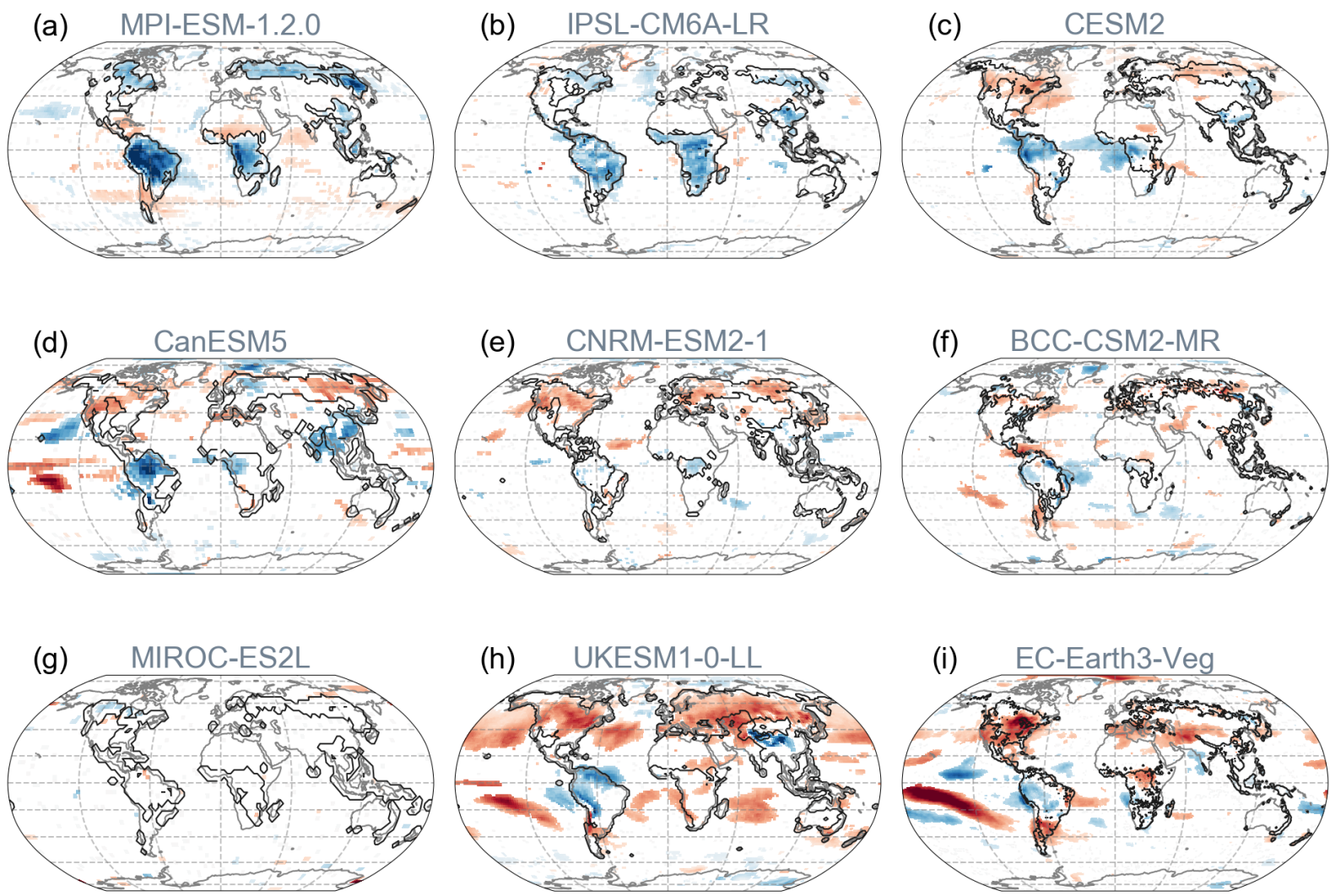

(h) UKESM1-0-LL
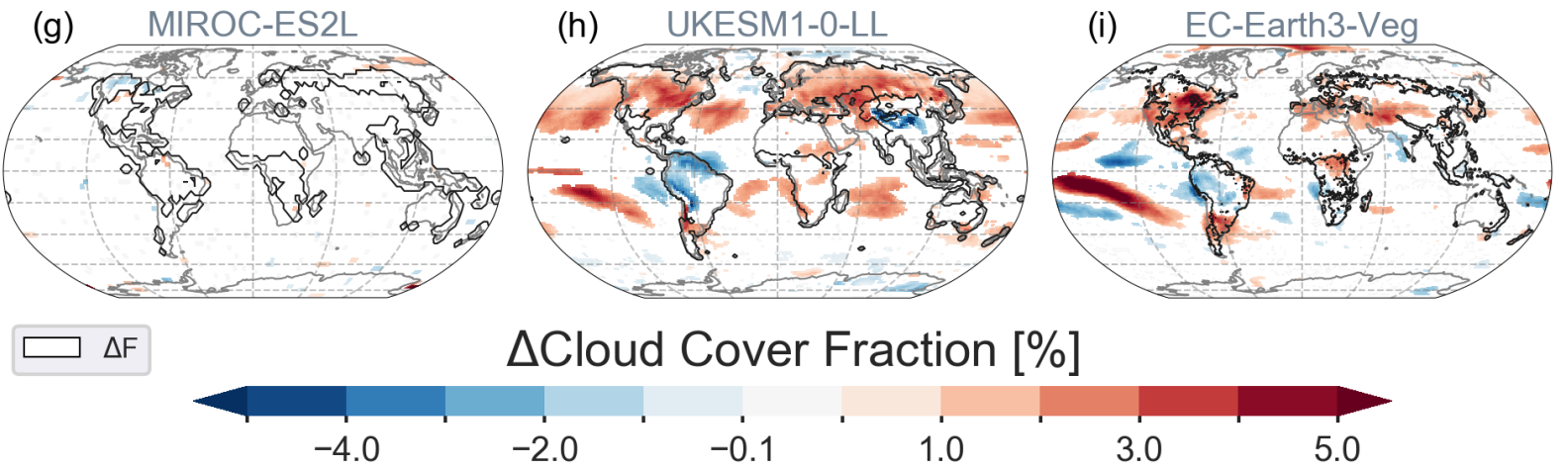

\section{$\Delta$ Cloud Cover Fraction [\%]}
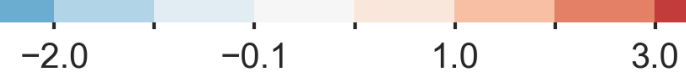

5.0

Fig. S6: Changes in total cloud cover fraction given in percent (mean over years t80 - t51). Only statistically significant changes are shown. 


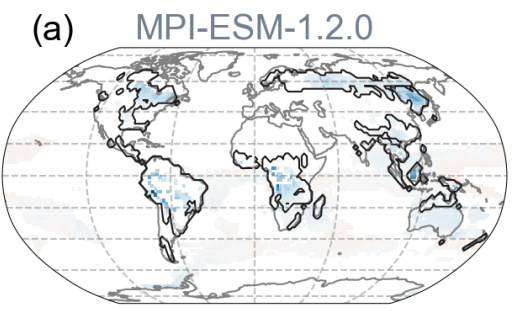

(b) IPSL-CM6A-LR

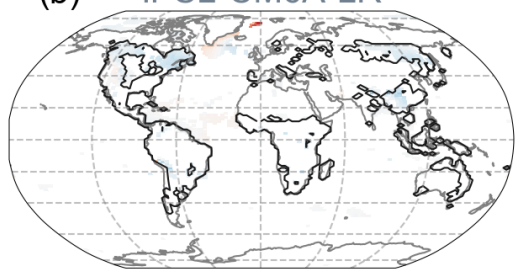

(d)

CanESM5

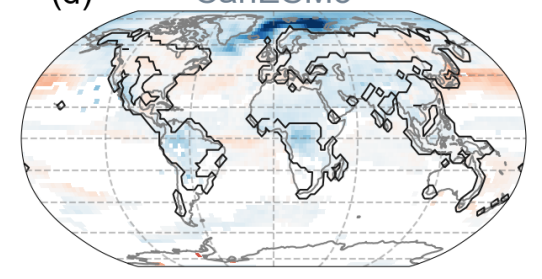

(e) CNRM-ESM2-1
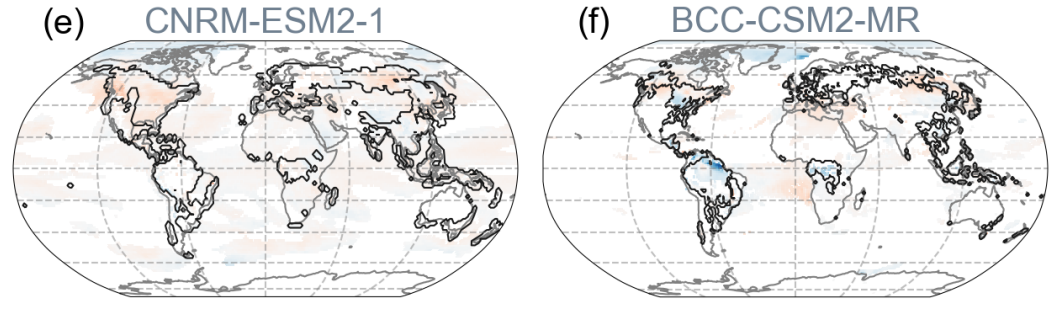

(g) MIROC-ES2L

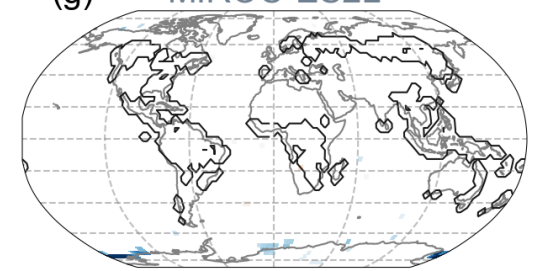

(h) UKESM1-0-LL

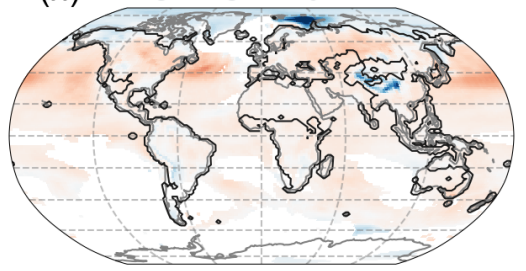

(i) EC-Earth3-Veg

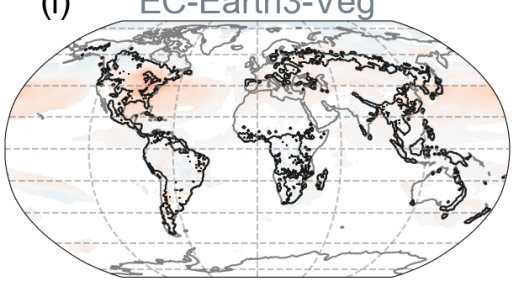

$\Delta \mathrm{F}$

$\Delta$ Longwave - $\Delta$ Longwave clear sky $\left[\mathrm{W} \mathrm{m}^{-2}\right]$

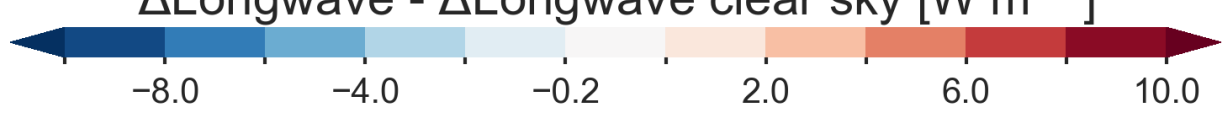

Fig. S7: Difference between downward all sky and clear sky longwave radiation ( $\mathrm{W} \mathrm{m}^{-2}$, mean over years t80 - t51). Only statistically significant changes are shown. Clear sky longwave radiation was not available for CESM2. 
(a) MPI-ESM-1.2.0

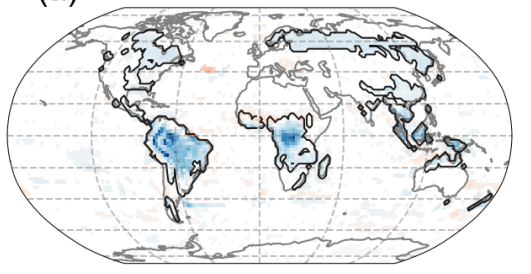

(d)

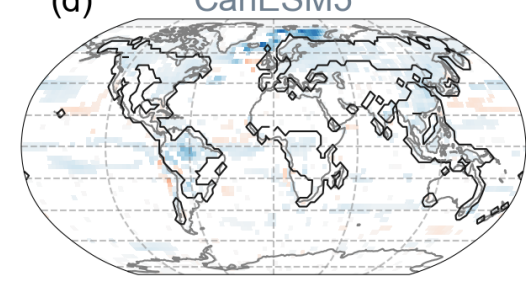

(g) MIROC-ES2L

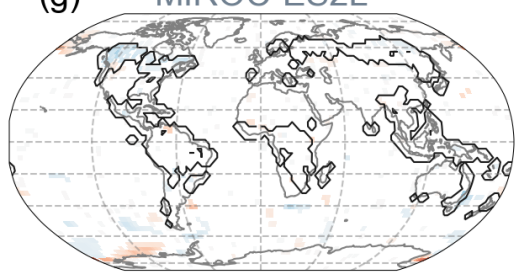

(h) UKESM1-0-LL
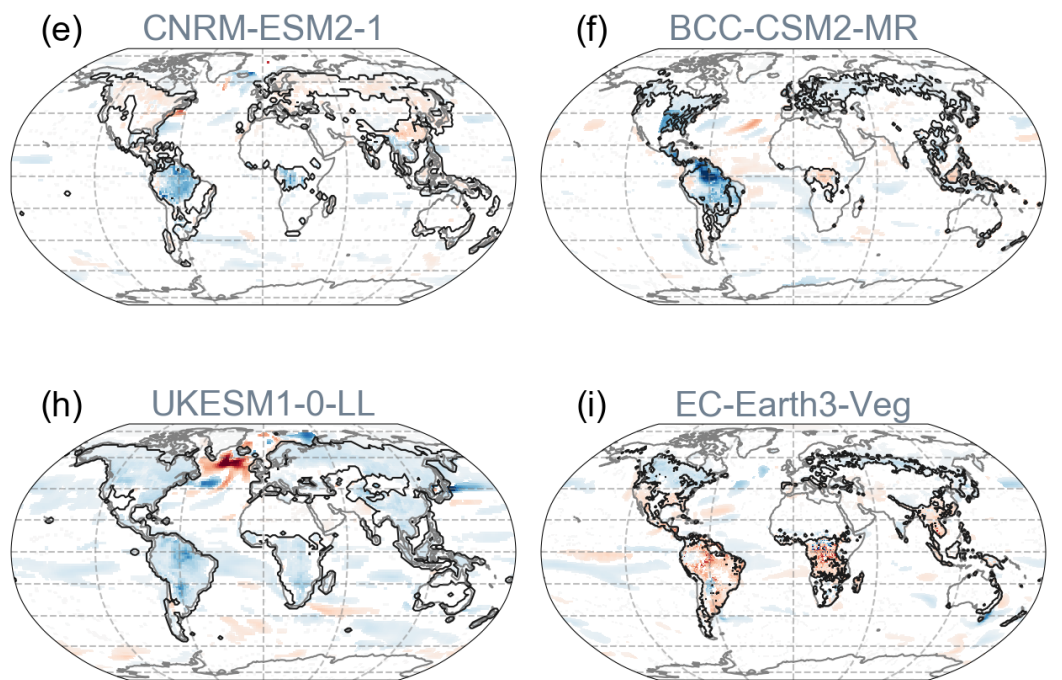

(i) EC-Earth3-Veg

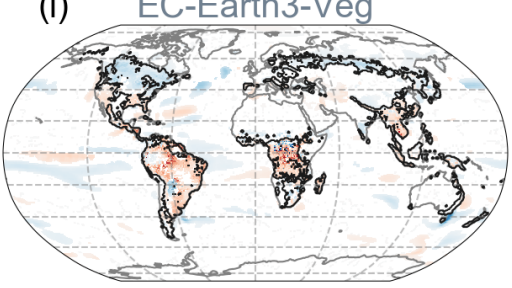

$\square \Delta \mathrm{F}$

$\Delta$ Evapotranspiration [mm year ${ }^{-1}$ ]

10

200

400

Fig. S8: Changes in evapotranspiration ( $\mathrm{mm}$ year ${ }^{-1}$; mean over years t80 - t51). Only statistically significant changes are shown. 
(a) MPI-ESM-1.2.0

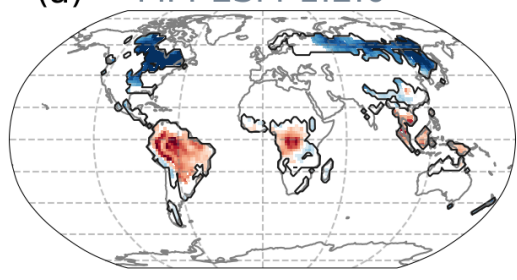

(d)

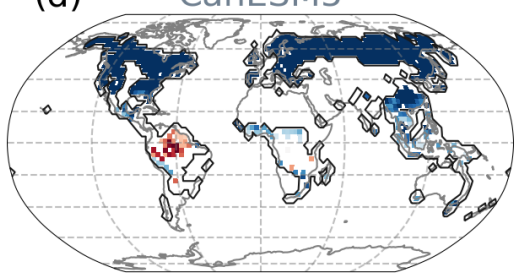

(b) IPSL-CM6A-LR
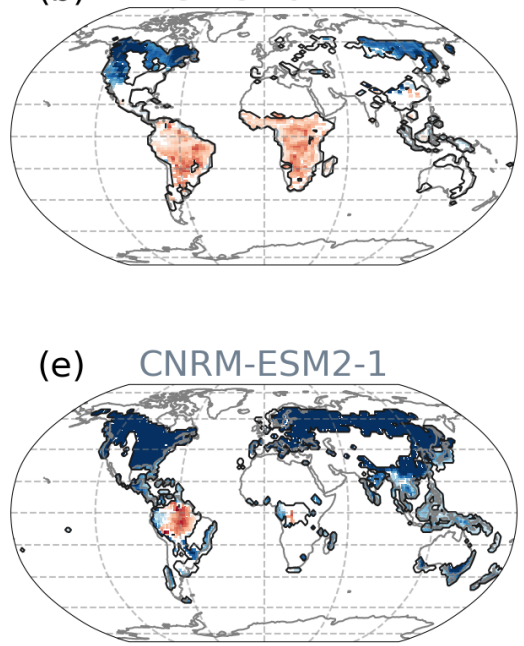

(e) CNRM-ESM2-1

(c) $\quad \mathrm{CESM} 2$

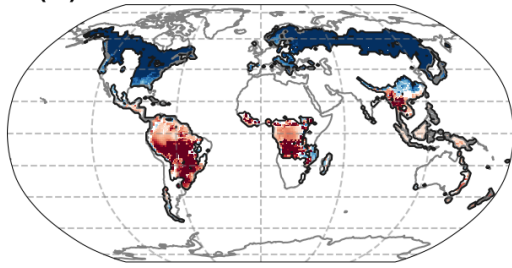

(f) $\quad$ BCC-CSM2-MR

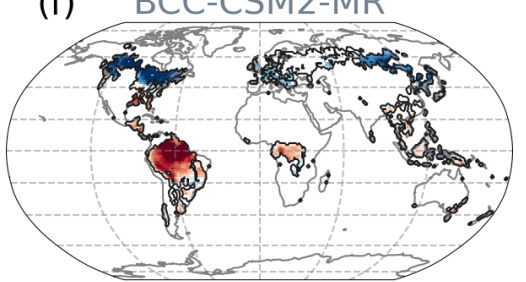

(i) EC-Earth3-Veg

(h) UKESM1-0-LL
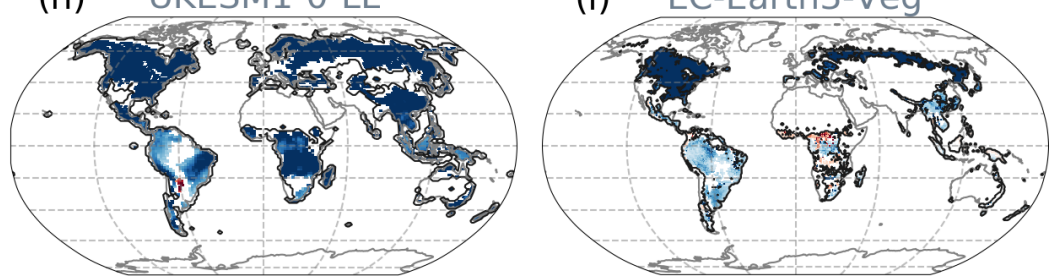

$\Delta \operatorname{Tas} \Delta \mathrm{F}^{-1}\left[{ }^{\circ} \mathrm{C} \mathrm{frac}^{-1}\right]$

1.00

2.00

Fig. S9: Changes in near-surface temperature $\Delta$ Tas scaled by the fraction of deforestation at year $t 50\left({ }^{\circ} \mathrm{C}\right.$ frac $^{-1}$; mean over years t 80 - t51). Only statistically significant changes are shown. 
(a) MPI-ESM-1.2.0

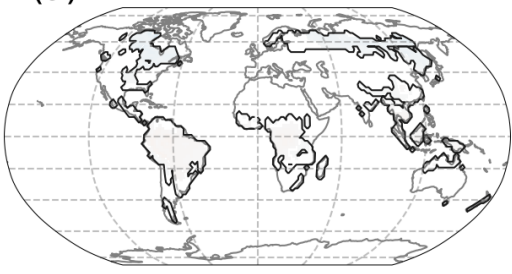

(d)

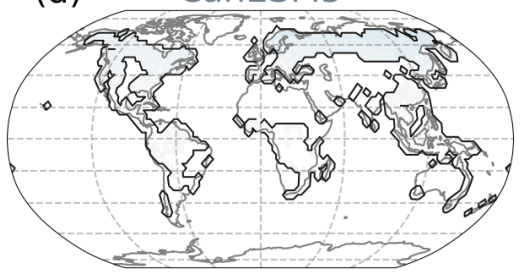

(g) MIROC-ES2L

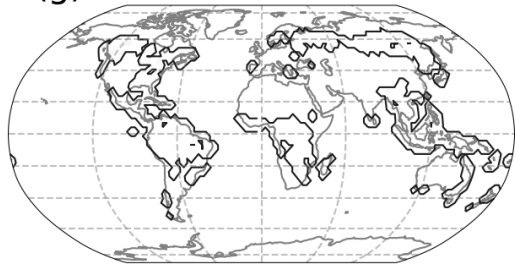

$\square \Delta \mathrm{F}$ (b) IPSL-CM6A-LR

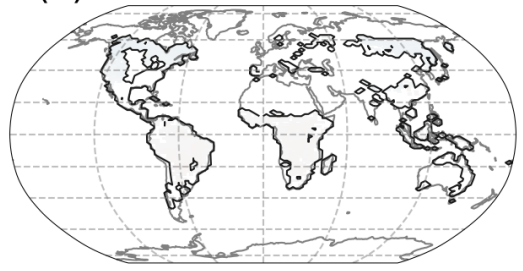

(e) CNRM-ESM2-1

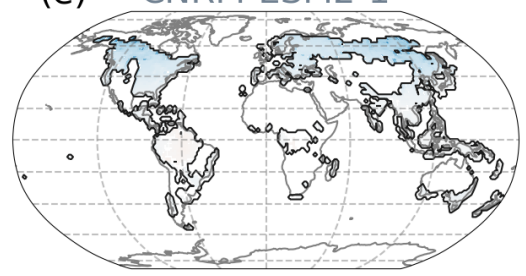

(h) UKESM1-0-LL
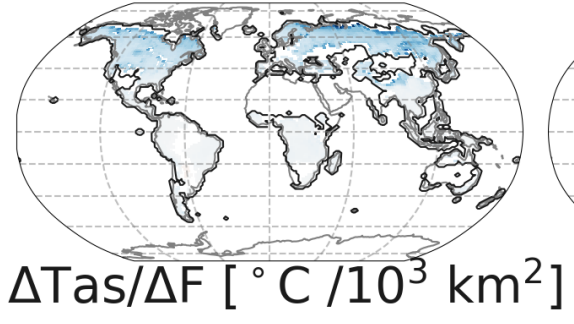
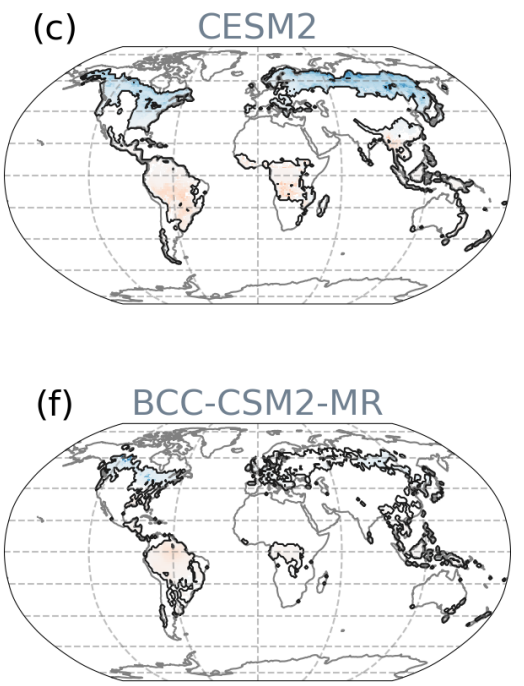

(f) BCC-CSM2-MR

(i) EC-Earth3-Veg

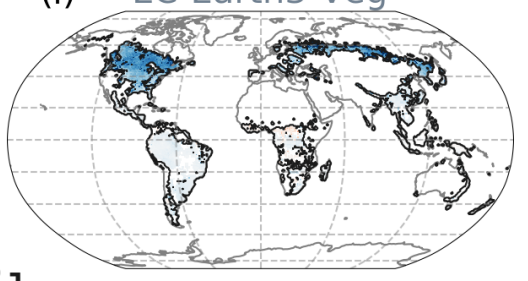

2.00

Fig. S10: Same as Fig. S9 but scaled with the area of deforestation at year t50 $\left({ }^{\circ} \mathrm{C}\right.$ per $1000 \mathrm{~km}^{2}$; mean over years t80 - t51). Only statistically significant changes are shown. 
(a) MPI-ESM-1.2.0

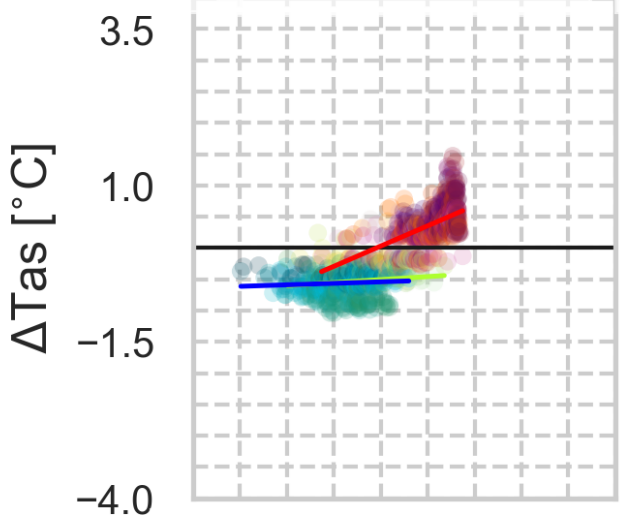

(d) CanESM5

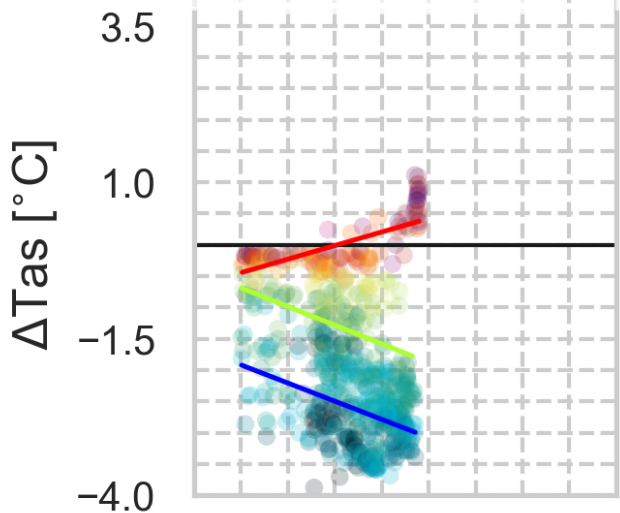

(g) MIROC-ES2L

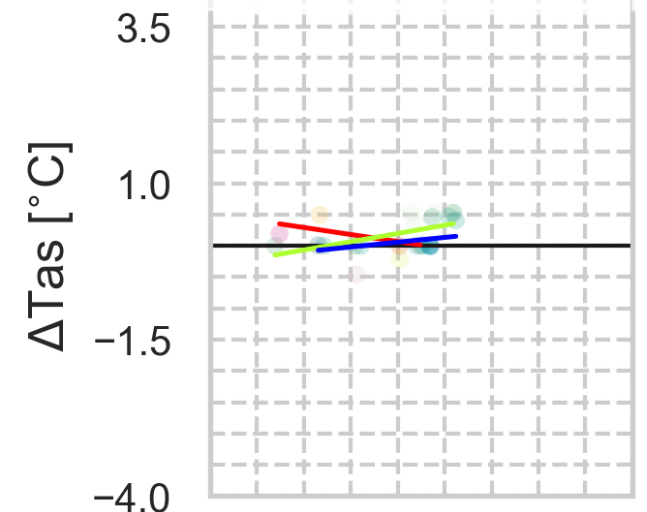

$-4.0$ (b) IPSL-CM6A-LR

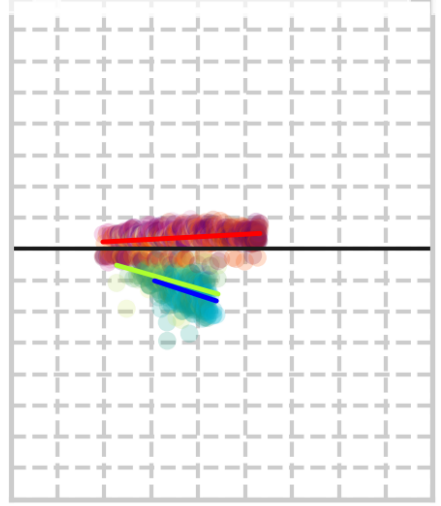

(e) CNRM-ESM2-1

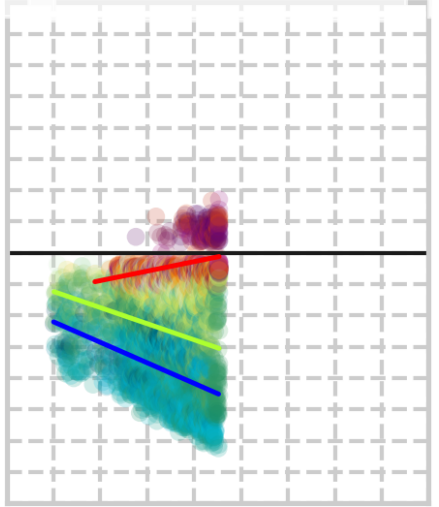

(h) UKESM1-0-LL

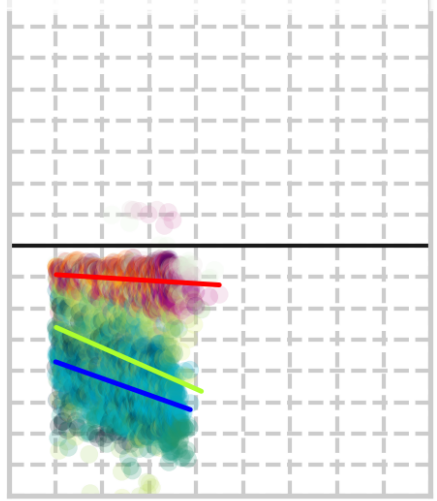

$$
\begin{array}{ccc}
20 \quad 40 \quad 60 \quad 80 \\
\Delta \mathrm{F}[\%]
\end{array}
$$

(c) $\mathrm{CESM} 2$

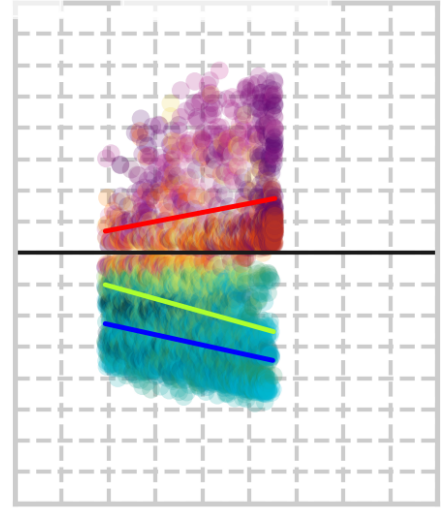

(f) BCC-CSM2-MR

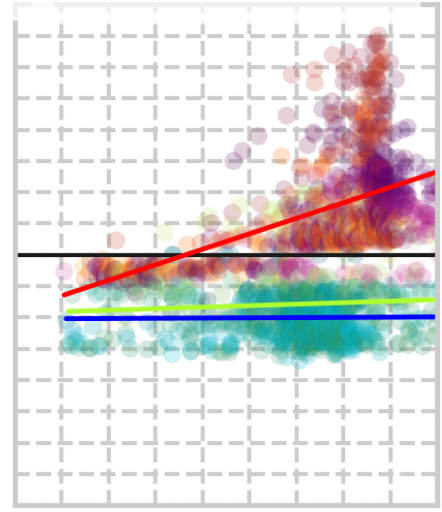

(i) EC-Earth3-Veg

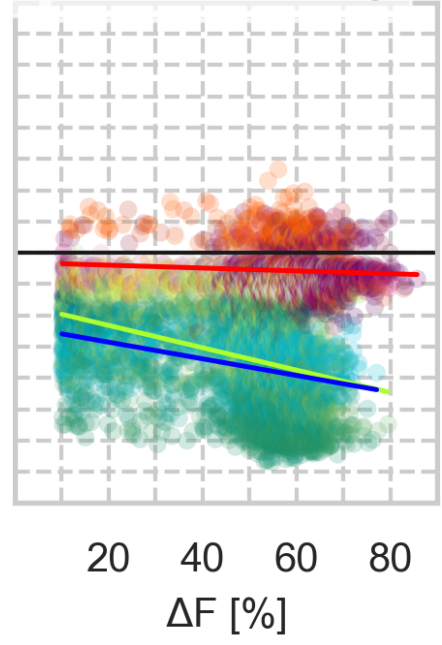

\begin{tabular}{c} 
tropics \\
temperate \\
\hline boreal
\end{tabular} $\Delta \mathrm{F}[\%]$

Latitude [deg]

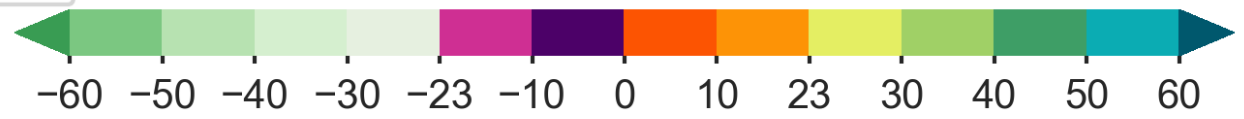

Fig S11: Relationship of changes in $\Delta$ Tas to changes in $\Delta \mathrm{F}(\%)$. Only grid cells with statistically significant changes as in Fig. 2 are selected. Lines denote a linear regression across tropical $\left(23^{\circ} \mathrm{S}\right.$ to $\left.23^{\circ} \mathrm{N}\right)$, temperate $\left(23^{\circ} \mathrm{N}\right.$ to $50^{\circ} \mathrm{N}$ and $23^{\circ} \mathrm{S}$ to $\left.50^{\circ} \mathrm{S}\right)$ and boreal regions $\left(>50^{\circ} \mathrm{N}\right)$. 

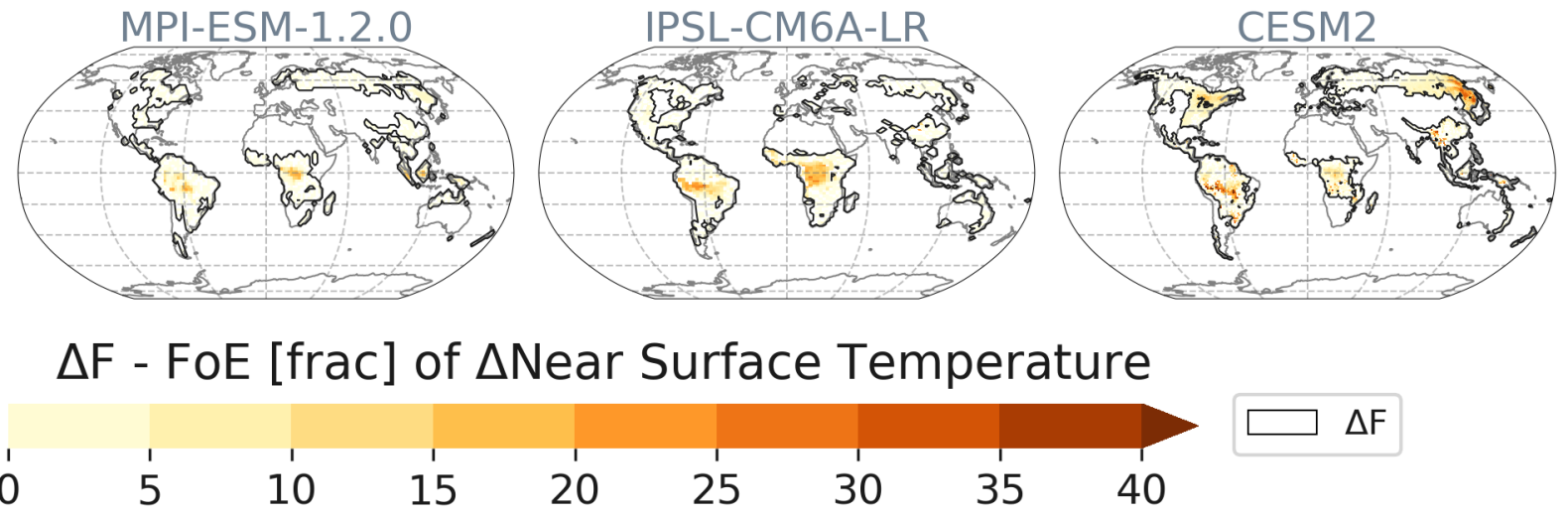

Fig. S12: Remaining deforestation fraction (in percent) after the time of emergence (ToE) of $\Delta$ Tas (Fig. 6) has been reached. 

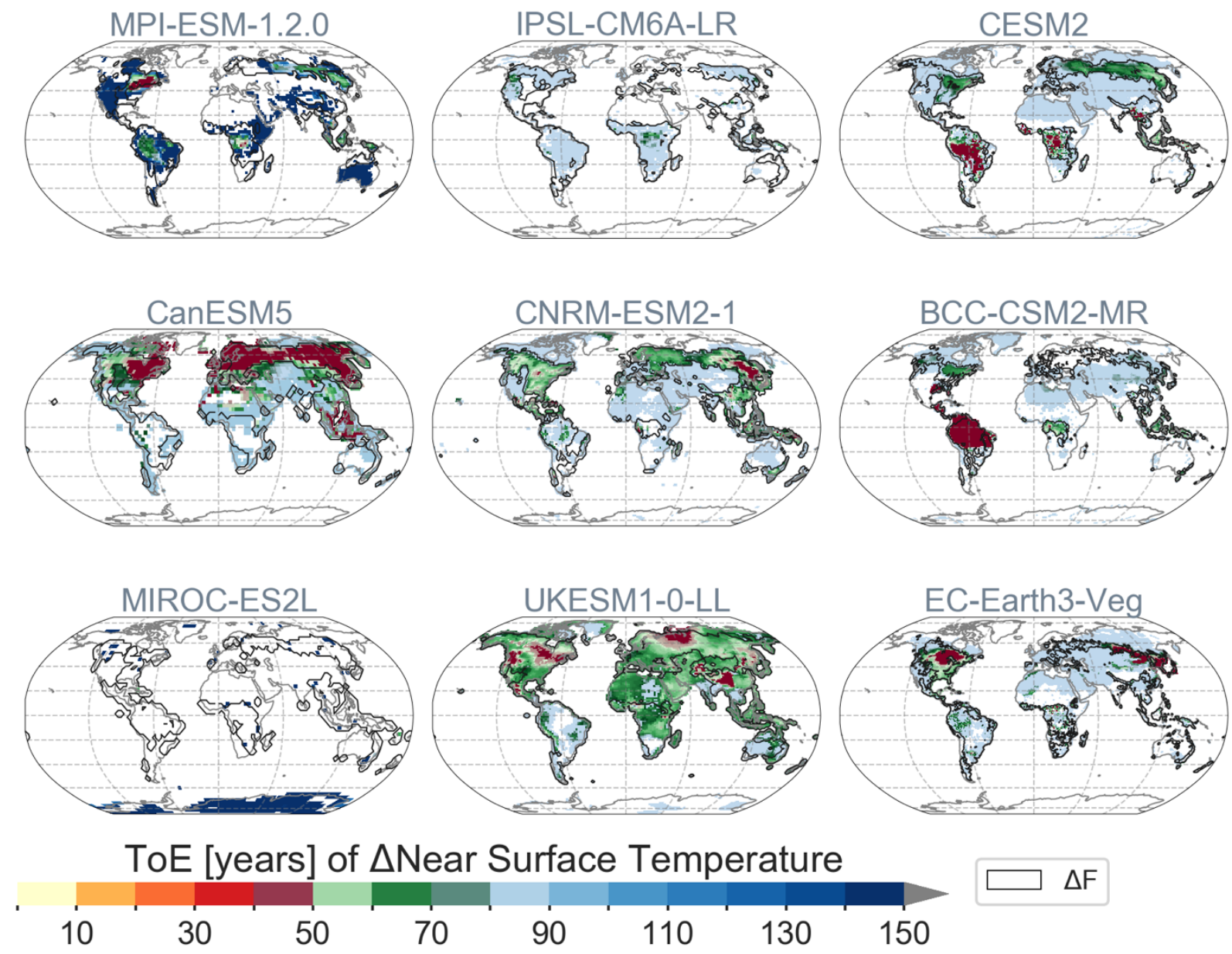

Fig. S13: Time of emergence (ToE) of $\Delta$ Tas using an alternative approach. The signal is defined as the running mean of 30 years and the noise is defined as the standard deviation across the first 30 years of the piControl simulation after the branching off of the deforest-globe simulation. The signal emerges if the signal-to-noise ratio exceeds one $(\mathrm{SNR}=1)$ and stays emergent after detection. Only statistically significant areas as found in Fig. 2 are shown. 


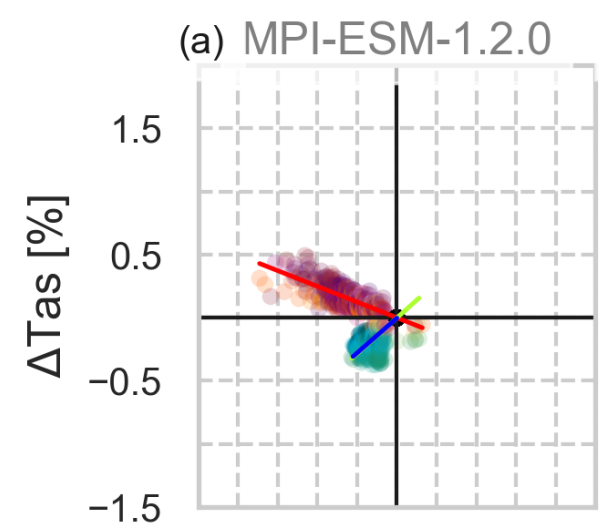

(b) IPSL-CM6A-LR

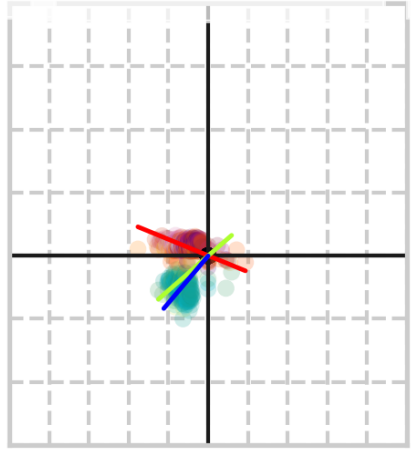

(d)

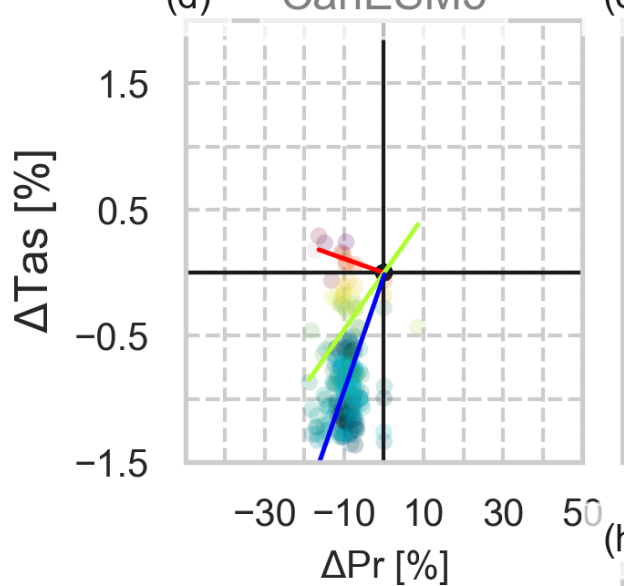

(e)

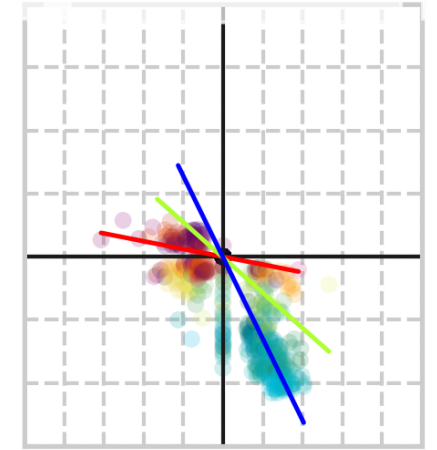

(h) UKESM1-0-LL

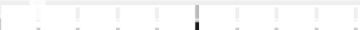

(e) CNRM-ESM2-1

(f) BCC-CSM2-MR

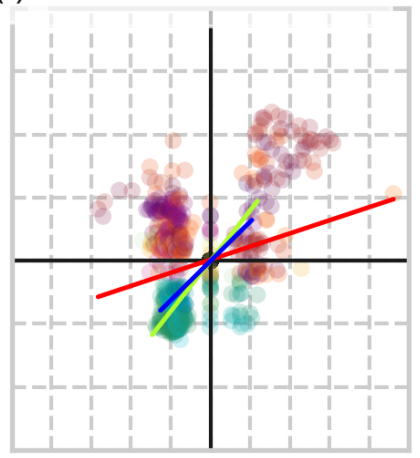

(i) EC-Earth3-Veg

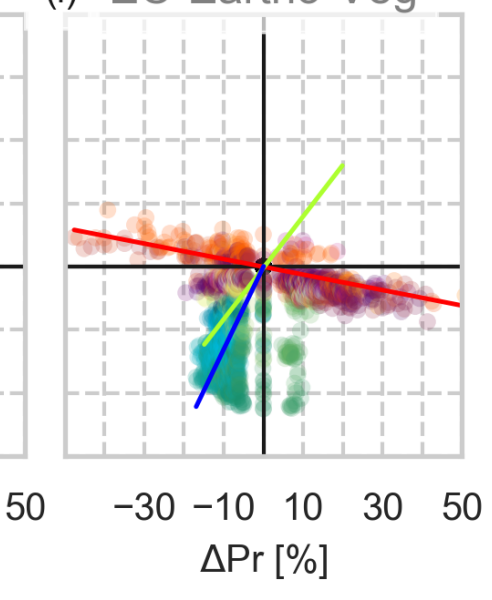

(

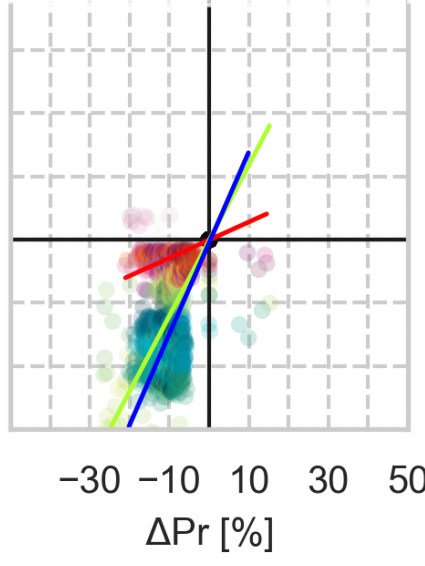

(c) $\mathrm{CESM} 2$
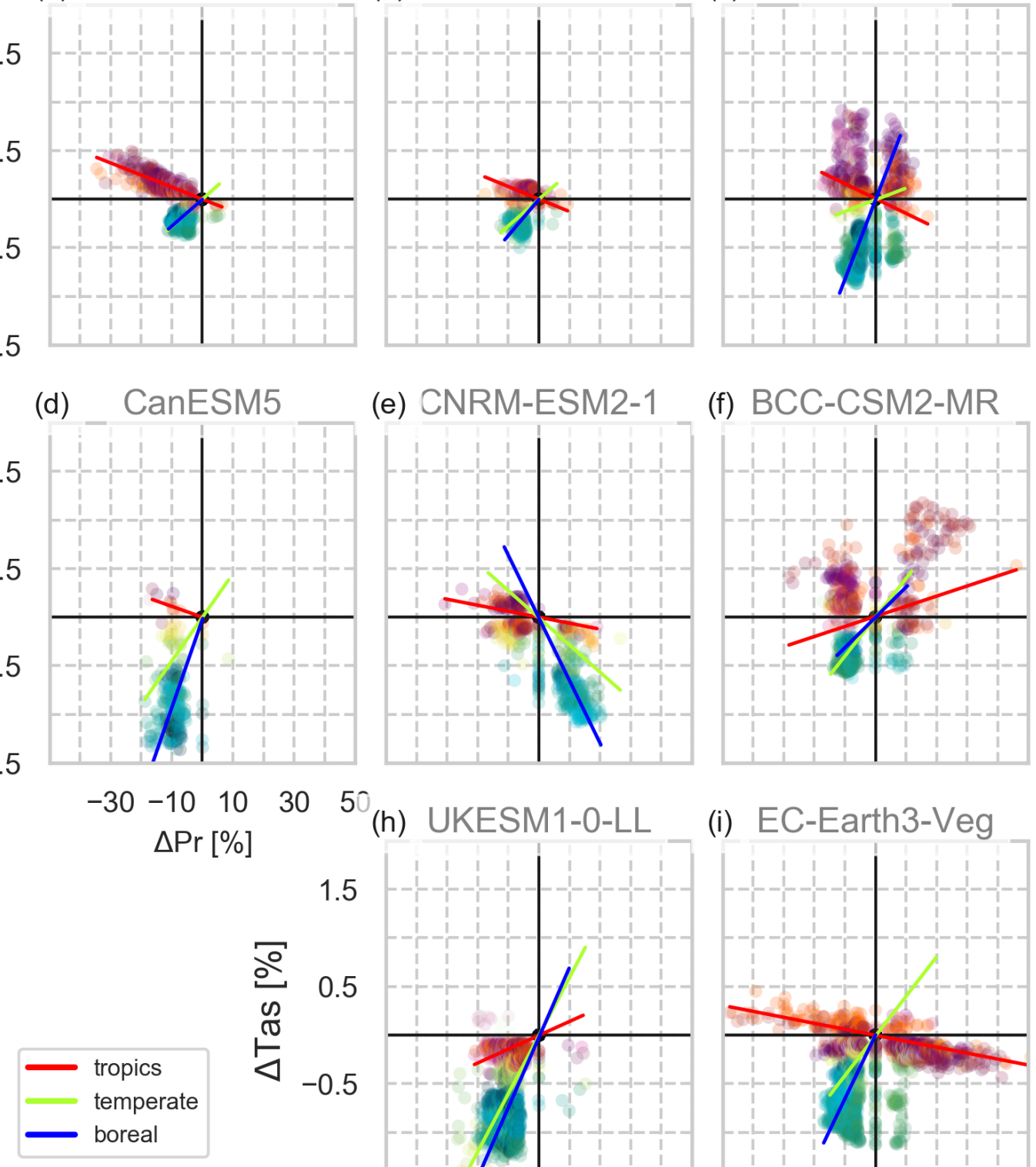

$-1.5$

\section{Latitude [deg]}

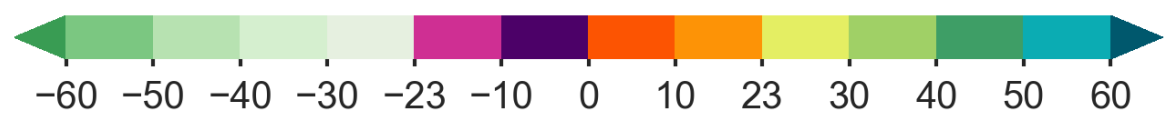

Fig. S14: Relationship of relative changes in near-surface temperature to relative changes in precipitation (in percent). Only statistically significant grid cells according to Fig. 3 and Fig. 7 are shown. Lines denote a linear regression across tropical $\left(23^{\circ} \mathrm{S}\right.$ to $\left.23^{\circ} \mathrm{N}\right)$, temperate $\left(23^{\circ} \mathrm{N}\right.$ to $50^{\circ} \mathrm{N}$ and $23^{\circ} \mathrm{S}$ to $\left.50^{\circ} \mathrm{S}\right)$ and boreal regions $\left(>50^{\circ} \mathrm{N}\right)$. 

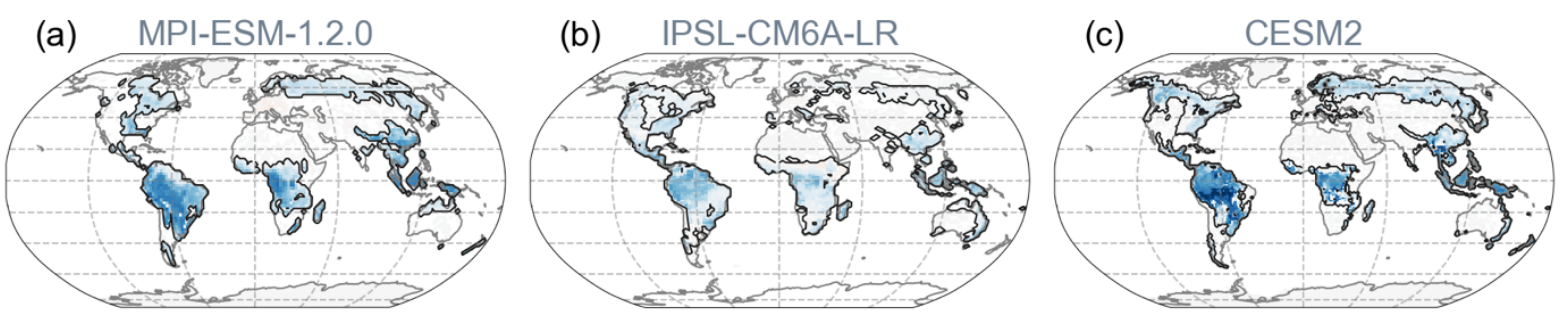

(e) CNRM-ESM2-1

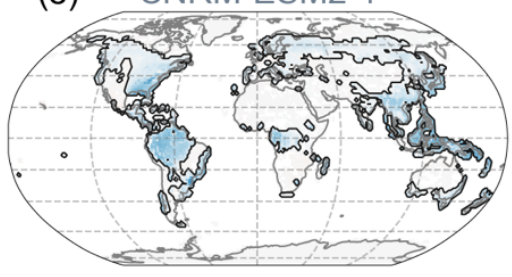

(g) MIROC-ES2L

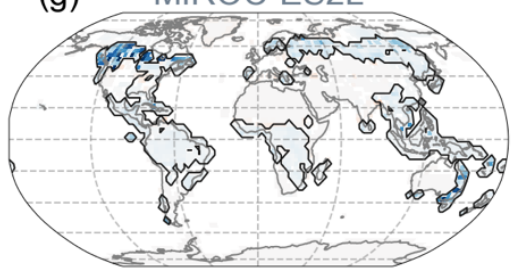

(h) UKESM1-0-LL

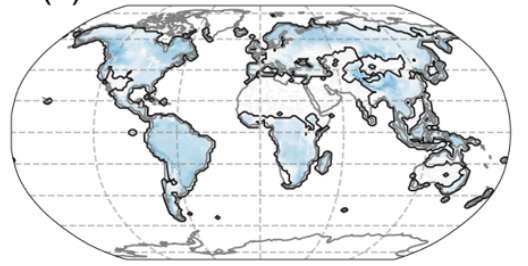

(i) EC-Earth3-Veg

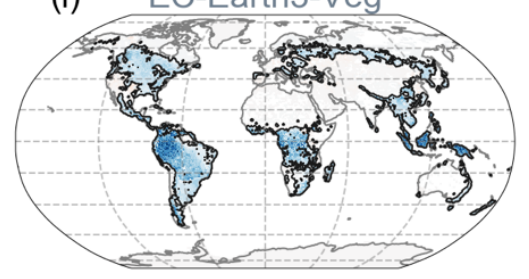

$\Delta \mathrm{F}$

$\Delta$ Total Land Carbon $\left[\mathrm{kg} \mathrm{m}^{-2}\right]$

$-15.0$

0.5

10.0

20.0

Fig S15: Changes in land carbon storage, cLand $\left(\mathrm{kg} \mathrm{m}^{-2}\right)$. Note, that CanESM and BCC did not follow the protocol when removing forests (see section 2.2) and are therefore not displayed for land carbon pools. 

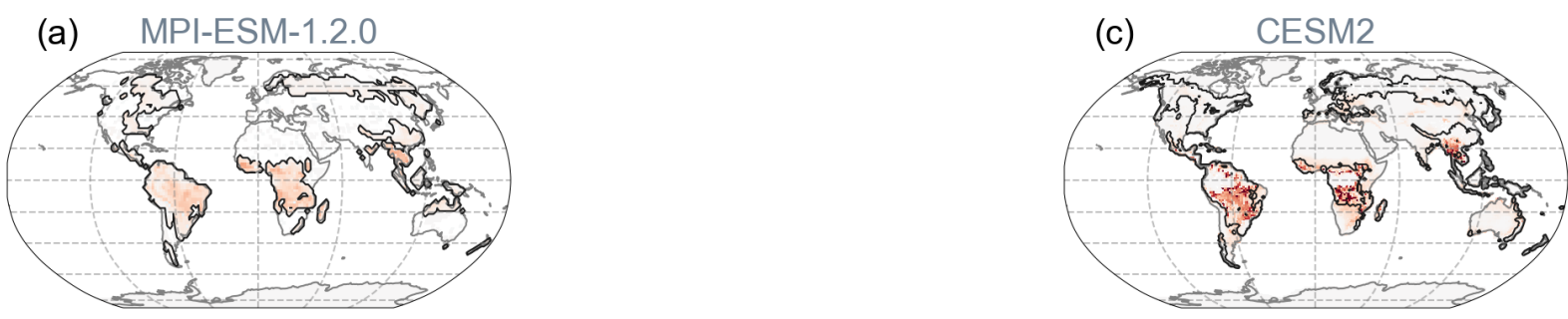

(e) EC-Earth3-Veg
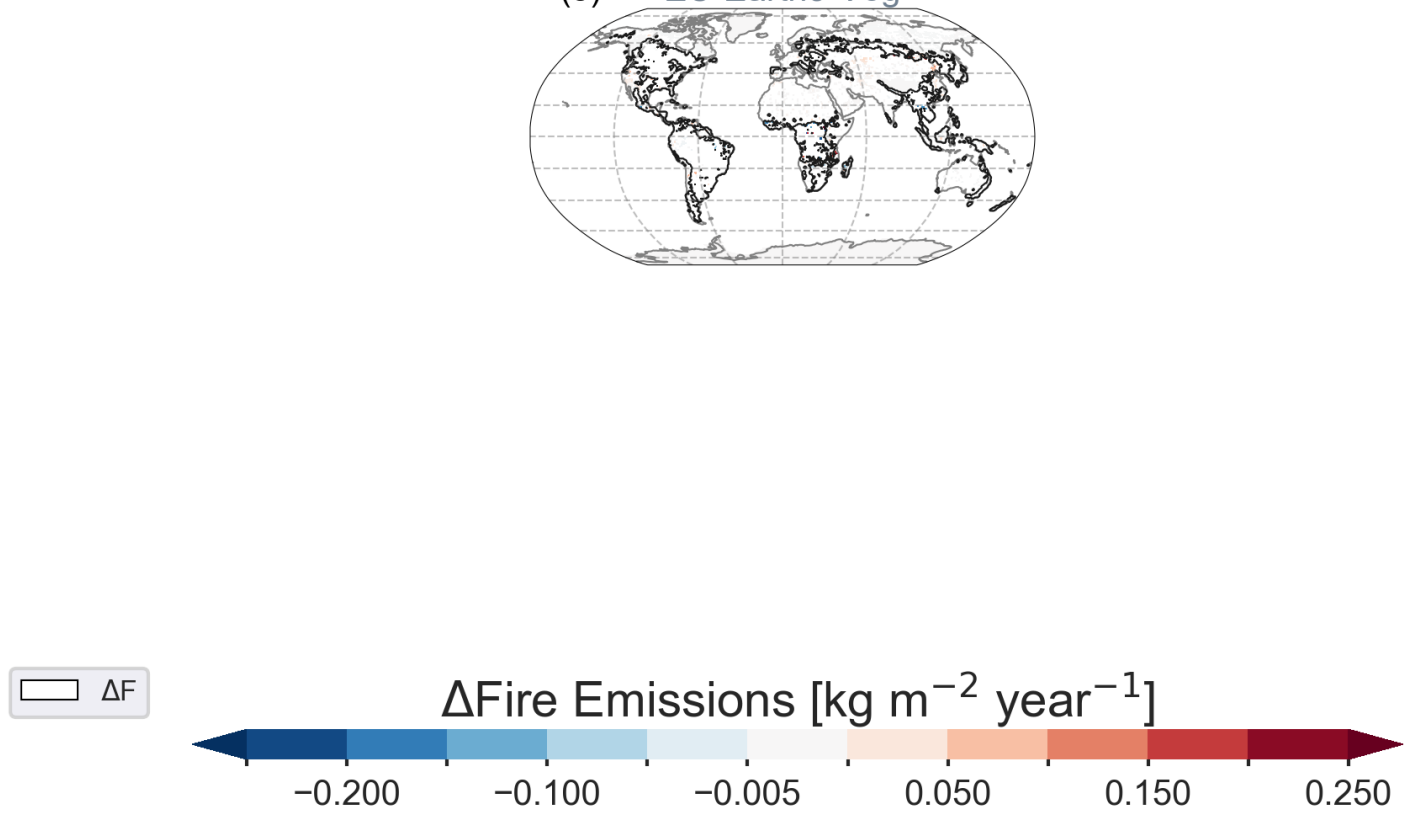

Fig. S16: Changes in emissions from fires $\left(\mathrm{kg} \mathrm{m}^{-2} \mathrm{year}^{-1}\right)$. Note, that only MPI, CESM2 and EC-Earth provided fire emissions. 


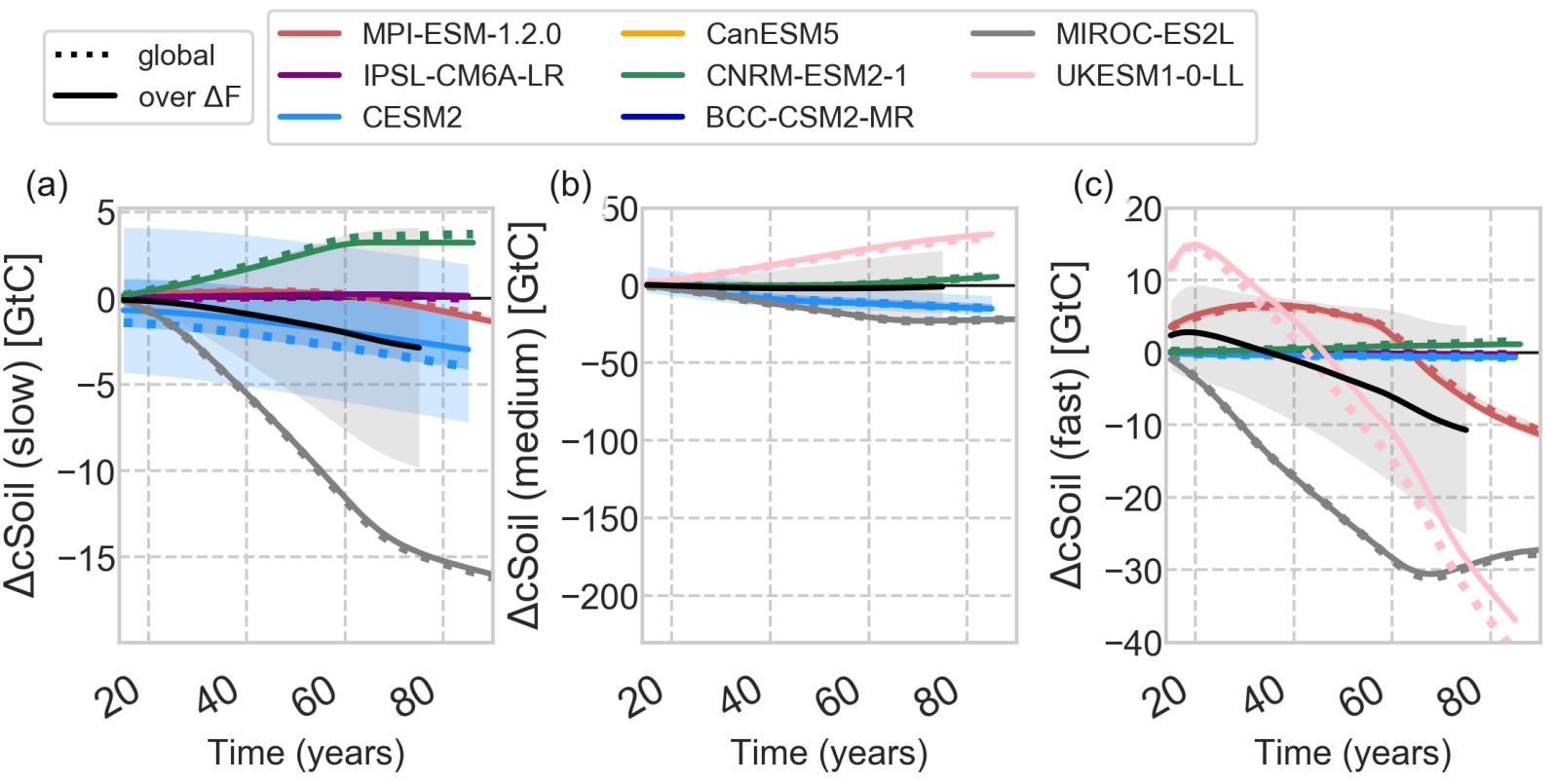

Fig. S17: Temporal changes in global soil carbon pools. Note, that not all models provide this distinction.
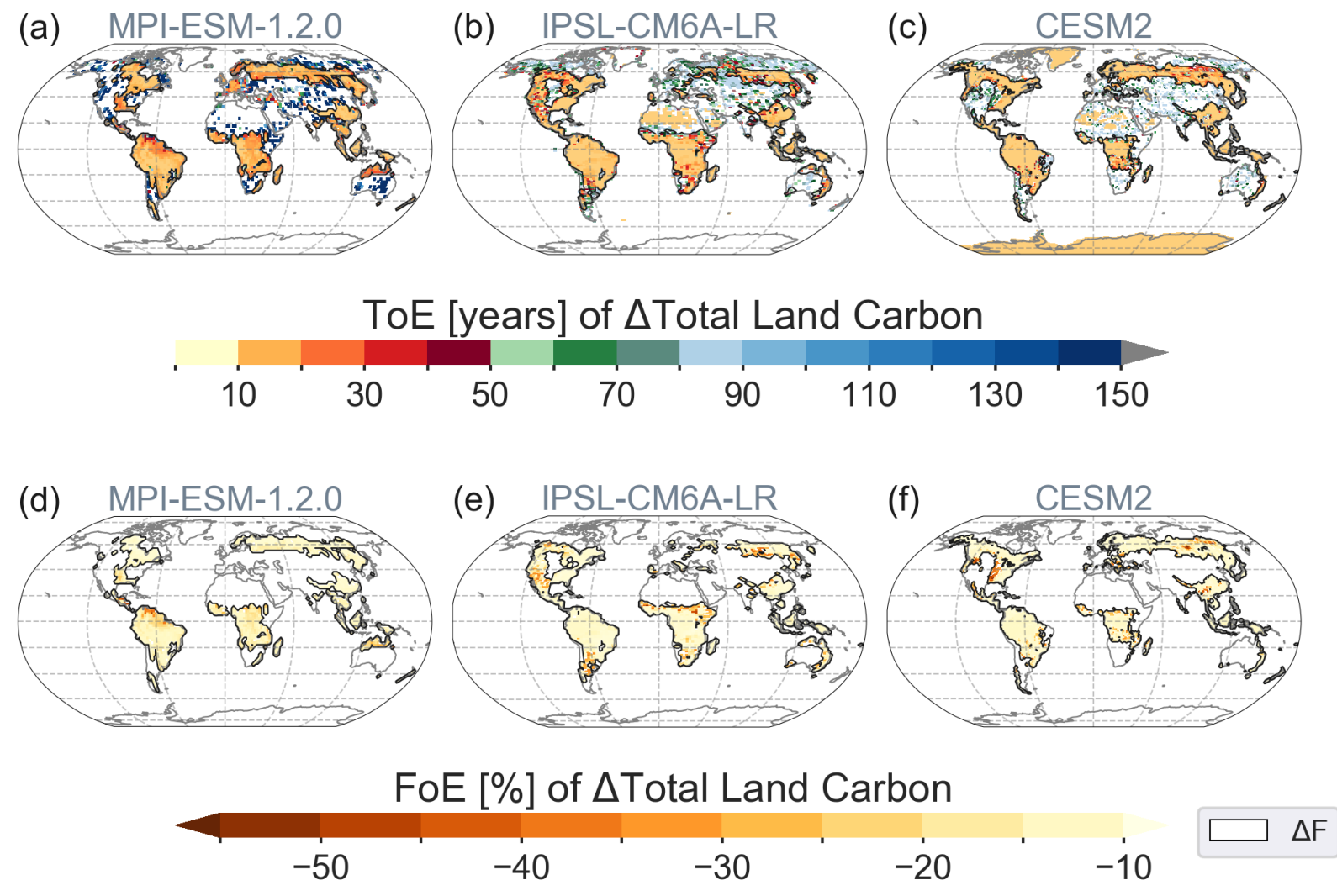

Fig. S18: ToE in years and the corresponding FoE in $\%$ of land carbon pools ( $\Delta$ cLand) using the method described in the manuscript and by (Schlunegger et al., 2019). cLand is the sum of cSoil, cVeg and cLitter. Only statistically significant changes of the mean (year t70 to t80) are shown. 


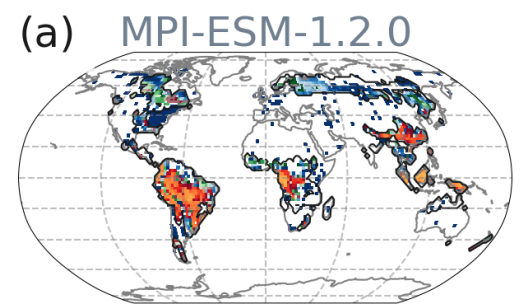

(b)

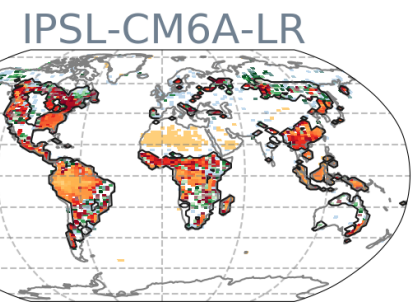

(c)

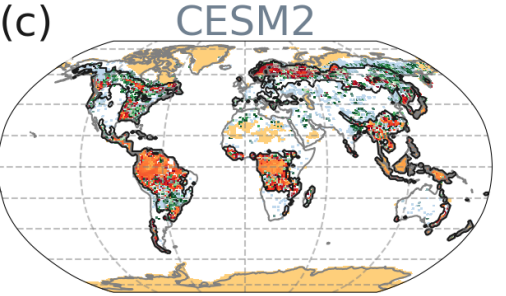

ToE [years] of $\triangle \mathrm{GPP}$
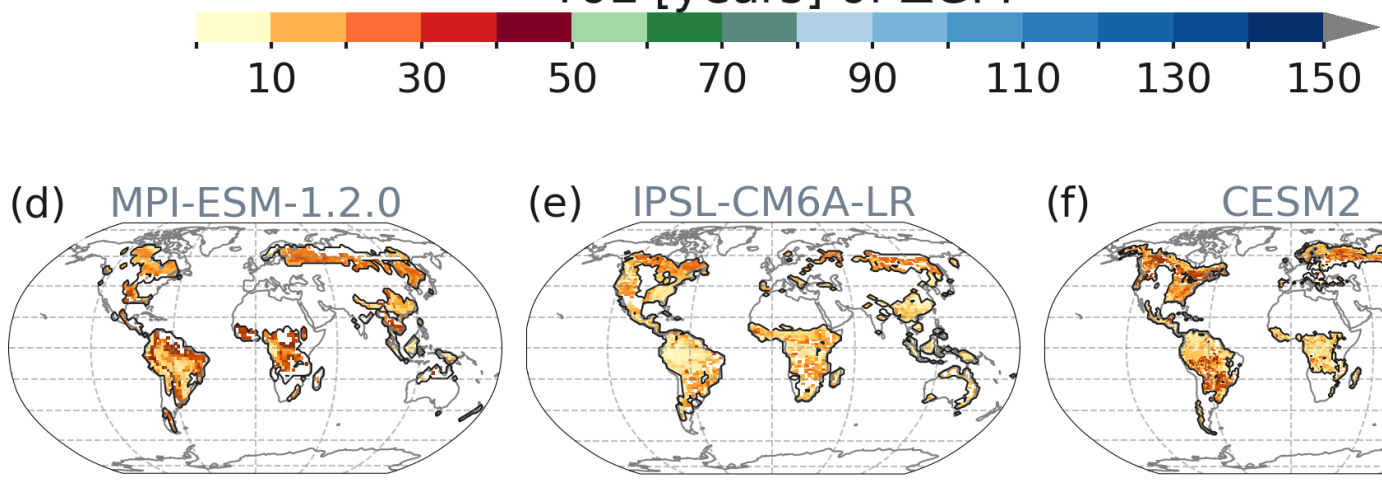

(e)

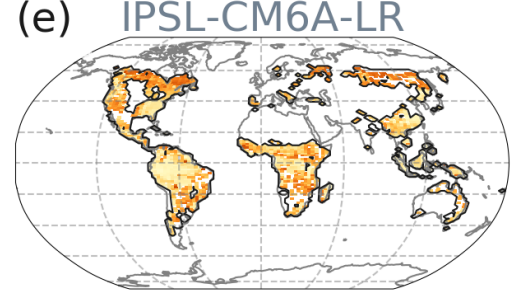

(f)

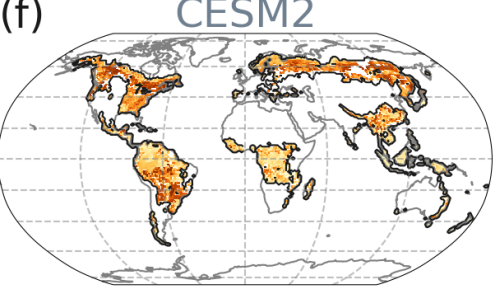

FoE [\%] of $\triangle \mathrm{GPP}$

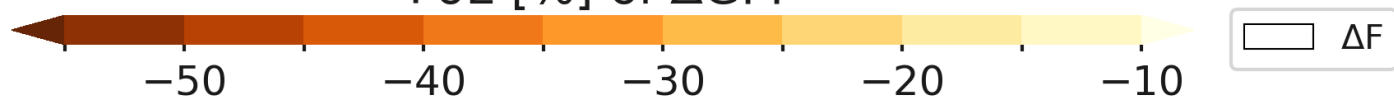

Fig. S19: Same as Fig S18 but for the ToE of gross primary productivity. 

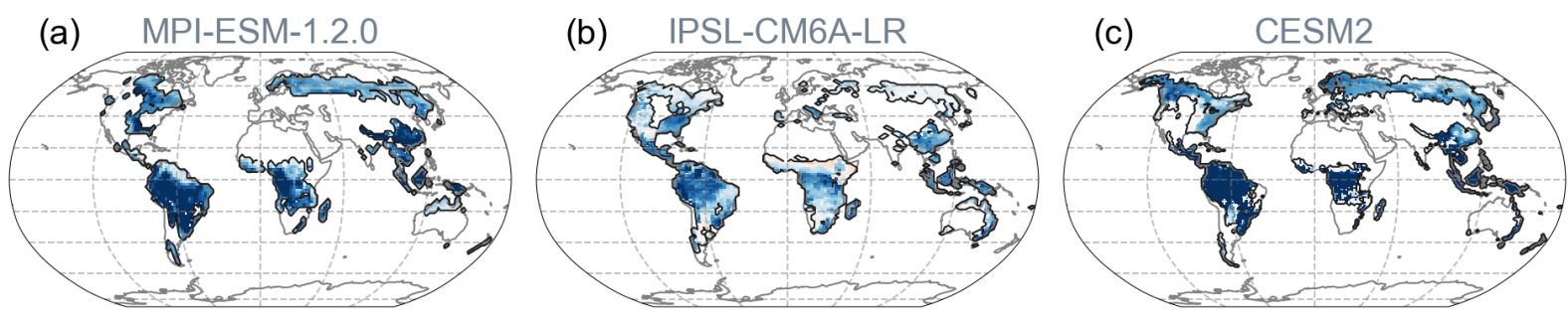

(e) CNRM-ESM2-1
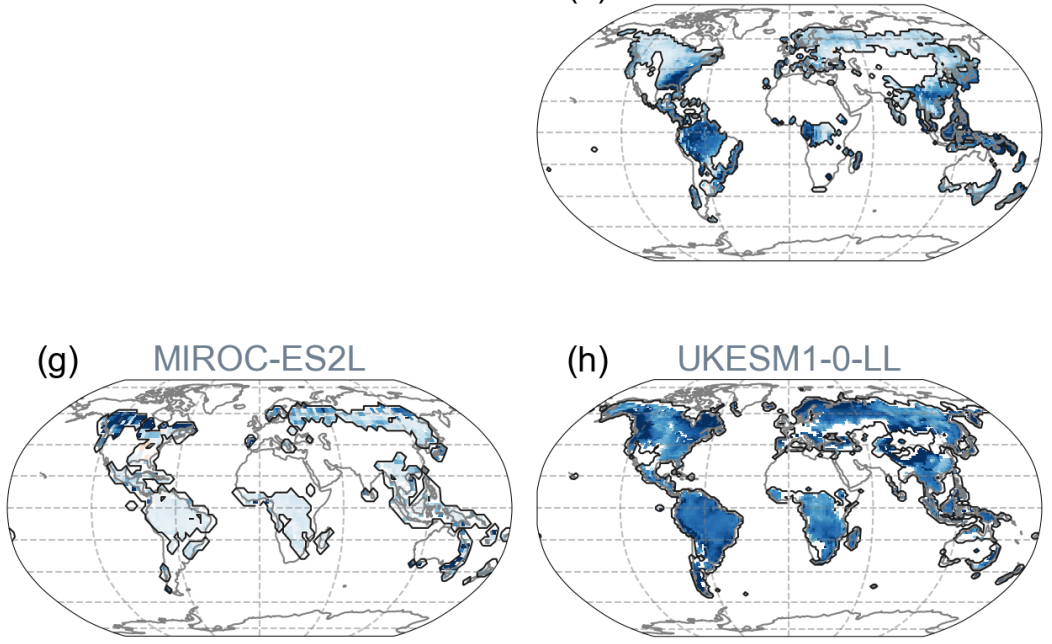

(h) UKESM1-0-LL
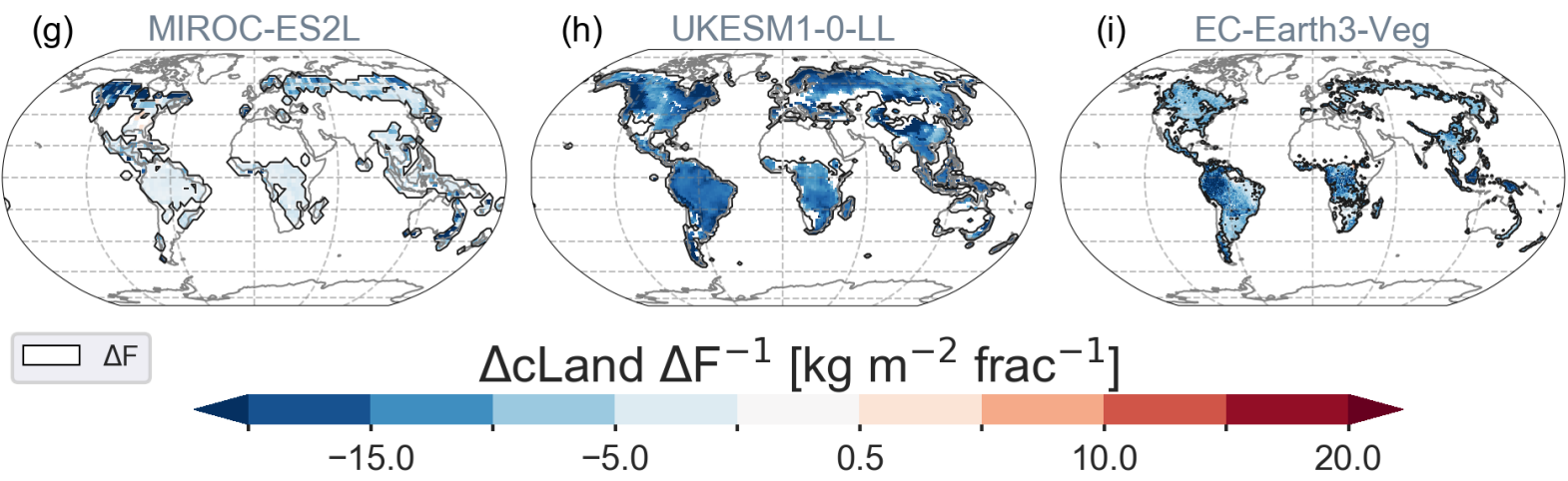

Fig. S20: Same as Fig. S9 but for $\triangle$ cLand. Note, that CanESM and BCC did not follow the protocol when removing forests (see section 2.2) and are therefore not displayed for land carbon pools. 

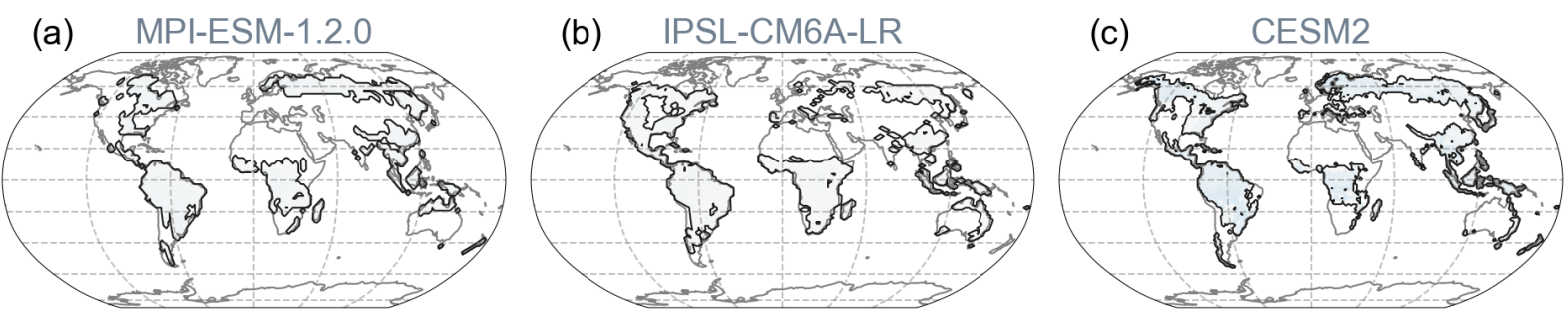

(e) CNRM-ESM2-1
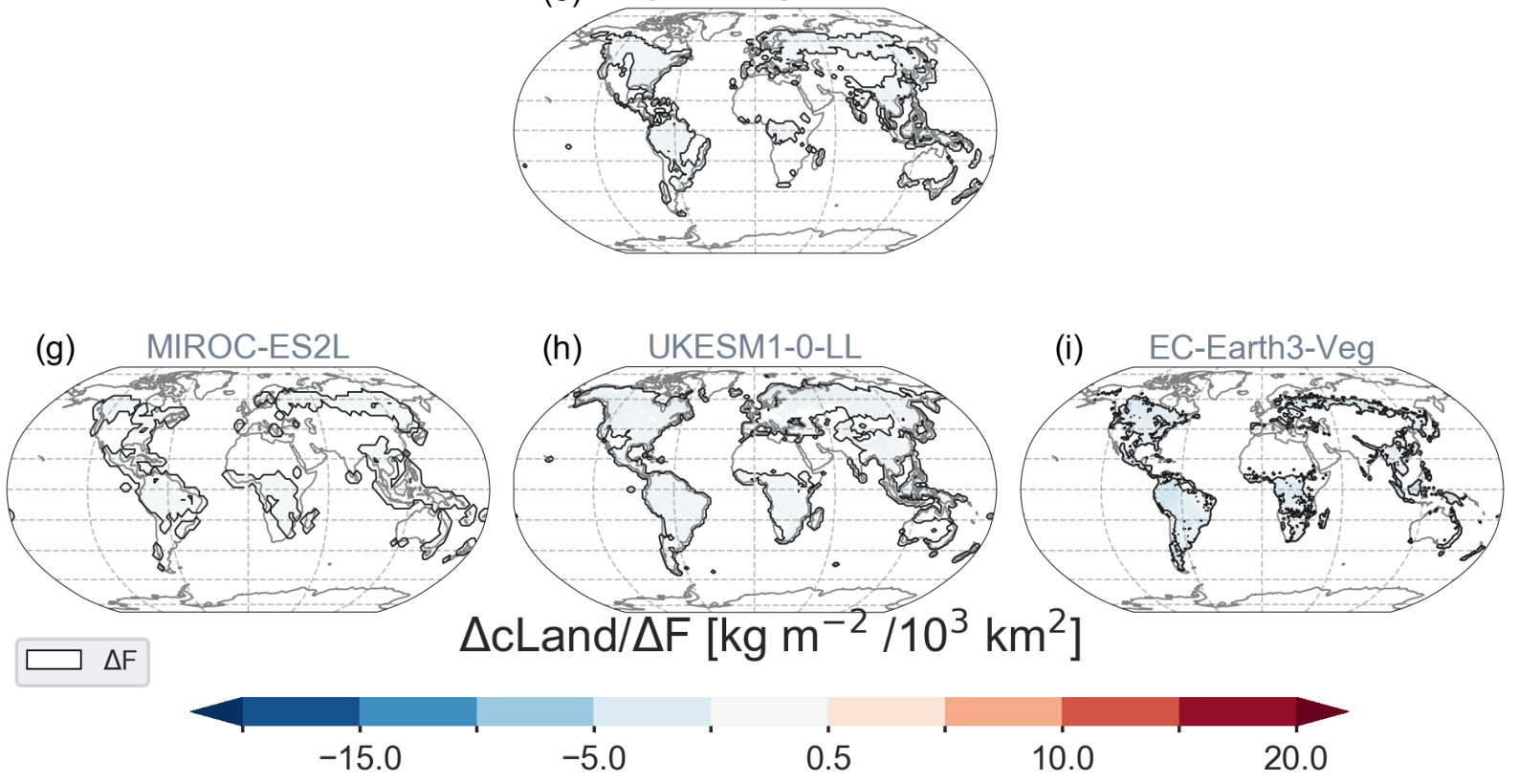

Fig. S21: Same as Fig. S10 but for $\triangle$ cLand. Note, that CanESM and BCC did not follow the protocol when removing forests (see section 2.2) and are therefore not displayed for land carbon pools.
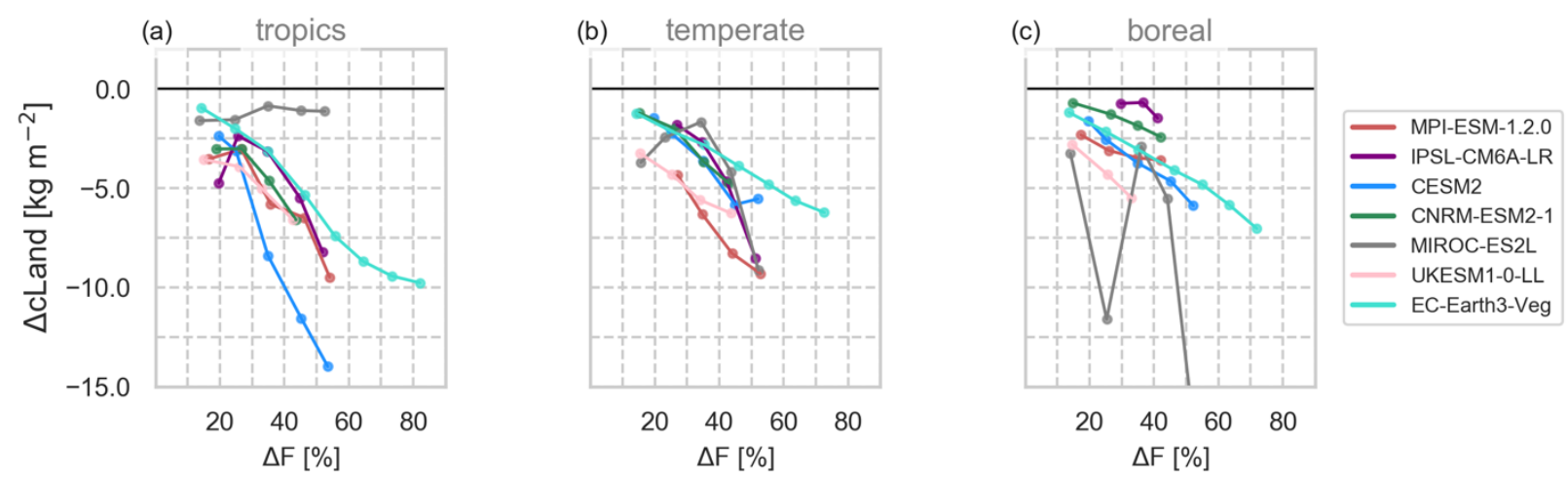

Fig. S22: Same as Fig. 4 in the manuscript but for $\triangle \mathrm{cLand}$. Note, that CanESM and BCC did not follow the protocol when removing forests (see section 2.2) and are therefore not displayed for land carbon pools. 
(a) MPI-ESM-1.2.0

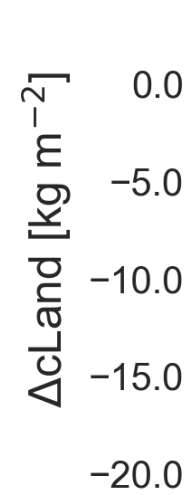

(b) IPSL-CM6A-LR

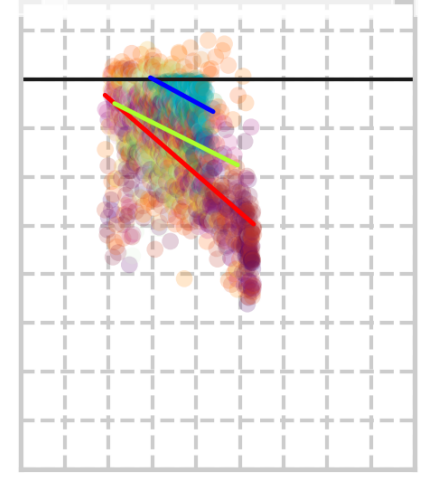

(e) CNRM-ESM2-1 (c) $\mathrm{CESM} 2$

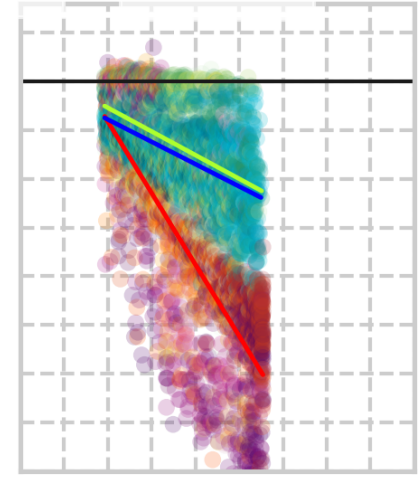

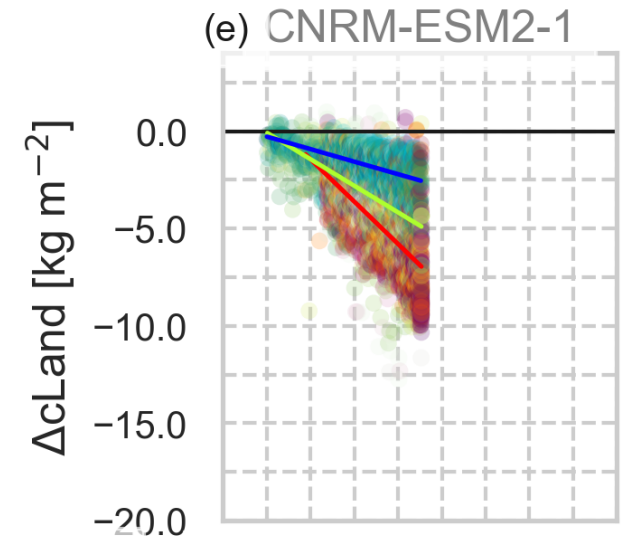

(g) MIROC-ES2L

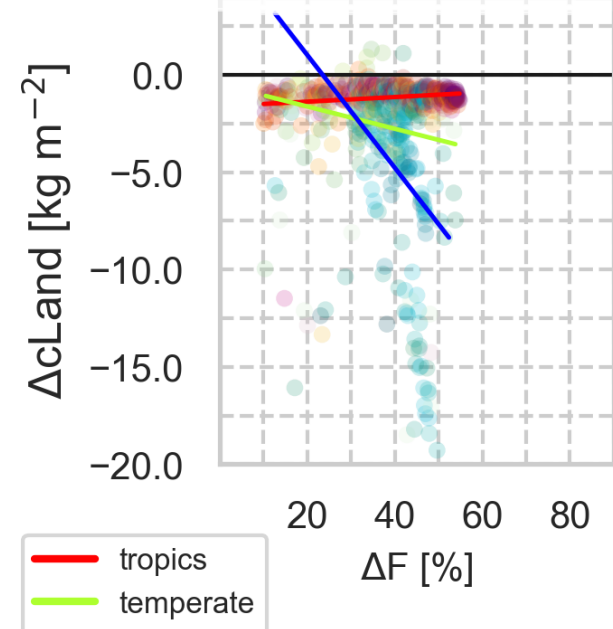

(h) UKESM1-0-LL

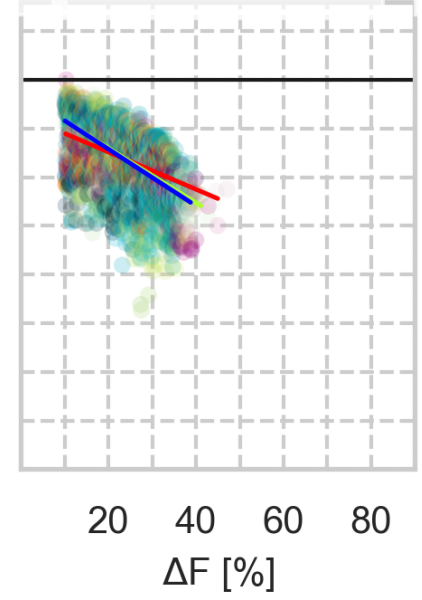

\section{Latitude [deg]}

(i) EC-Earth3-Veg

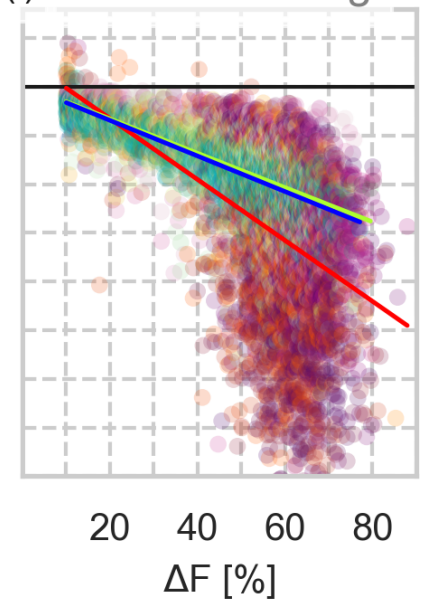

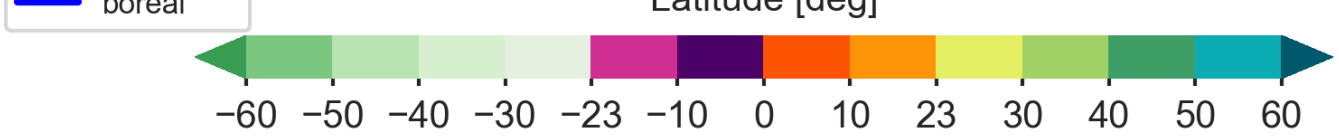

Fig. S23: Same as Fig. S11 but for $\Delta$ cLand. 


\section{References:}

Arora, V., Scinocca, J., Boer, G., Christian, J., Denman, K., Flato, G., Kharin, V., Lee, W. and Merryfield, W.: Carbon emission limits required to satisfy future representative concentration pathways of greenhouse gases, Geophysical Research Letters, 38(5), L05805, 2011.

Arora, V. K., Katavouta, A., Williams, R. G., Jones, C. D., Brovkin, V., Friedlingstein, P., Schwinger, J., Bopp, L., Boucher, O., Cadule, P., Chamberlain, M. A., Christian, J. R., Delire, C., Fisher, R. A., Hajima, T., Ilyina, T., Joetzjer, E., Kawamiya, M., Koven, C., Krasting, J., Law, R. M., Lawrence, D. M., Lenton, A., Lindsay, K., Pongratz, J., Raddatz, T., Séférian, R., Tachiiri, K., Tjiputra, J. F., Wiltshire, A., Wu, T. and Ziehn, T.: Carbon-concentration and carbon-climate feedbacks in CMIP6 models, and their comparison to CMIP5 models, Biogeosciences Discussions, 1-124, doi:https://doi.org/10.5194/bg-2019-473, 2019.

Berthet, S., Séférian, R., Bricaud, C., Chevallier, M., Voldoire, A. and Ethé, C.: Evaluation of an Online Grid-Coarsening Algorithm in a Global Eddy-Admitting Ocean Biogeochemical Model, Journal of Advances in Modeling Earth Systems, 11(6), 1759-1783, doi:10.1029/2019MS001644, 2019.

Boucher, O., Servonnat, J. and Albright, A. L.: Presentation and evaluation of the IPSL-CM6A-LR climate model., n.d.

Boussetta, S., Balsamo, G., Beljaars, A., Kral, T. and Jarlan, L.: Impact of a satellite-derived leaf area index monthly climatology in a global numerical weather prediction model, International Journal of Remote Sensing, 34(9-10), 3520-3542, doi:10.1080/01431161.2012.716543, 2013.

Christian, J. R., Arora, V. K., Boer, G. J., Curry, C. L., Zahariev, K., Denman, K. L., Flato, G. M., Lee, W. G., Merryfield, W. J., Roulet, N. T. and Scinocca, J. F.: The global carbon cycle in the Canadian Earth system model (CanESM1): Preindustrial control simulation, Journal of Geophysical Research, 115(G3), doi:10.1029/2008JG000920, 2010.

Clark, D. B., Mercado, L. M., Sitch, S., Jones, C. D., Gedney, N., Best, M. J., Pryor, M., Rooney, G. G., Essery, R. L. H., Blyth, E., Boucher, O., Harding, R. J., Huntingford, C. and Cox, P. M.: The Joint UK Land Environment Simulator (JULES), model description - Part 2: Carbon fluxes and vegetation dynamics, Geoscientific Model Development, 4(3), 701-722, doi:https://doi.org/10.5194/gmd-4-701-2011, 2011.

Coleman, K., Jenkinson, D., Crocker, G., Grace, P., Klir, J., Körschens, M., Poulton, P. and Richter, D.: Simulating trends in soil organic carbon in long-term experiments using RothC-26.3, Geoderma, 81(1), 2944, 1997.

Craig, A., Valcke, S. and Coquart, L.: Development and performance of a new version of the OASIS coupler, OASIS3-MCT_3.0, Geoscientific Model Development, 10(9), 3297-3308, doi:10.5194/gmd-103297-2017, 2017.

Danabasoglu, G., Lamarque, J. -F., Bacmeister, J., Bailey, D. A., DuVivier, A. K., Edwards, J., Emmons, L. K., Fasullo, J., Garcia, R., Gettelman, A., Hannay, C., Holland, M. M., Large, W. G., Lauritzen, P. H., Lawrence, D. M., Lenaerts, J. T. M., Lindsay, K., Lipscomb, W. H., Mills, M. J., Neale, R., Oleson, K. W., Otto-Bliesner, B., Phillips, A. S., Sacks, W., Tilmes, S., Kampenhout, L., Vertenstein, M., Bertini, A., Dennis, J., Deser, C., Fischer, C., Fox-Kemper, B., Kay, J. E., Kinnison, D., Kushner, P. J., Larson, V. E., Long, M. C., Mickelson, S., Moore, J. K., Nienhouse, E., Polvani, L., Rasch, P. J. and Strand, W. G.: The Community Earth System Model Version 2 (CESM2), Journal of Advances in Modeling Earth Systems, 12(2), doi:10.1029/2019MS001916, 2020. 
Decharme, B., Delire, C., Minvielle, M., Colin, J., Vergnes, J., Alias, A., Saint-Martin, D., Séférian, R., Sénési, S. and Voldoire, A.: Recent Changes in the ISBA-CTRIP Land Surface System for Use in the CNRM-CM6 Climate Model and in Global Off-Line Hydrological Applications, Journal of Advances in Modeling Earth Systems, 11(5), 1207-1252, doi:10.1029/2018MS001545, 2019.

Delire, C., Séférian, R., Decharme, B., Alkama, R., Calvet, J.-C., Carrer, D., Gibelin, A.-L., Joetzjer, E., Morel, X., Rocher, M. and Tzanos, D.: The global land carbon cycle simulated with ISBA-CTRIP: improvements over the last decade, Journal of Advances in Modeling Earth Systems, n/a(n/a), e2019MS001886, doi:10.1029/2019MS001886, 2020.

Doescher, R., Hardenberg, J. v., Wyser, K., Noije, T. v., le Sager, P., Fladrich, U., Koenigk, T., O’Donnell, D., Miller, P. A., Groeger, M., Willén, U., Ménégoz, M., Carver, G., Bousetta, S., Arneth, A., Caron, L.P., Bernadello, R., Sicardi, V., Touigny, E., Ortega, P., Arsouze, T., Castrillo, M., Prims, O. T., Echevarria, P., Ramos, A., Moreno-Chamarro, E., Cvijanovic, I., Ruprich-Robert, Y., Uotila, P., Acosta, M., YepesArbós, X., Doblas-Reyes, F. J., Nolan, P., v. d. Oord, G., Reerink, T., Nieradzik, L. P., Bergmann, T., Anthoni, P., Warlind, D., Smith, B., Dekker, E., Davini, P., Serva, F., Catalano, F., Alessandri, A., Madsen, M. S., Yang, S., Wang, S., Schmidt, T., Tian, T., Massonnet, F., Makkonen, R., Ollinaho, P., Schröder, R., Keskinen, J.-P., Rousset, C. and Vancoppenolle, M.: The EC-Earth3 Earth System Model for the Climate Model Intercomparison Project 6., n.d.

Goll, D. S., Brovkin, V., Liski, J., Raddatz, T., Thum, T. and Todd-Brown, K. E. O.: Strong dependence of $\mathrm{CO} 2$ emissions from anthropogenic land cover change on initial land cover and soil carbon parametrization, Global Biogeochem. Cycles, 29(9), 2014GB004988, doi:10.1002/2014GB004988, 2015.

Goll, D. S., Winkler, A. J., Raddatz, T., Dong, N., Prentice, I. C., Ciais, P. and Brovkin, V.: Carbon-nitrogen interactions in idealized simulations with JSBACH (version 3.10), Geosci. Model Dev. Discuss., 2017, $1-$ 28, doi:10.5194/gmd-2016-304, 2017.

Goudriaan, J., van Laar, H. H., van Keulen, H. and Louwerse, W.: Photosynthesis, CO2 and Plant Production, in Wheat Growth and Modelling, edited by W. Day and R. K. Atkin, pp. 107-122, Springer US, Boston, MA., 1985.

Hagemann, S. and Stacke, T.: Impact of the soil hydrology scheme on simulated soil moisture memory, Clim Dyn, 44(7-8), 1731-1750, doi:10.1007/s00382-014-2221-6, 2015.

Hajima, T., Watanabe, M., Yamamoto, A., Tatebe, H., Noguchi, M. A., Abe, M., Ohgaito, R., Ito, A., Yamazaki, D., Okajima, H., Ito, A., Takata, K., Ogochi, K., Watanabe, S. and Kawamiya, M.: Development of the MIROC-ES2L Earth system model and the evaluation of biogeochemical processes and feedbacks, Geoscientific Model Development, 13(5), 2197-2244, doi:10.5194/gmd-13-2197-2020, 2020.

Harper, A. B., Cox, P. M., Friedlingstein, P., Wiltshire, A. J., Jones, C. D., Sitch, S., Mercado, L. M., Groenendijk, M., Reich, P. B. and Others, A. T.: Improved representation of plant functional types and physiology in the Joint UK Land Environment Simulator (JULES v4.2) using plant trait information, Geoscientific Model Development, 2415-2440, doi:10.5194/gmd-9-2415-2016, 2016.

Hasumi, H.: CCSR Ocean Component Model (COCO) Version 4.0 February 16, 2006, Center for Climate System Research, University of Tokyo., 2006.

Hazeleger, W., Wang, X., Severijns, C., Ştefănescu, S., Bintanja, R., Sterl, A., Wyser, K., Semmler, T., Yang, S., van den Hurk, B., van Noije, T., van der Linden, E. and van der Wiel, K.: EC-Earth V2.2: 
description and validation of a new seamless earth system prediction model, Clim Dyn, 39(11), 2611-2629, doi:10.1007/s00382-011-1228-5, 2012.

Hurtt, G. C., Chini, L., Sahajpal, R., Frolking, S., Bodirsky, B. L., Calvin, K., Doelman, J. C., Fisk, J., Fujimori, S., Goldewijk, K. K., Hasegawa, T., Havlik, P., Heinimann, A., Humpenöder, F., Jungclaus, J., Kaplan, J., Kennedy, J., Kristzin, T., Lawrence, D., Lawrence, P., Ma, L., Mertz, O., Pongratz, J., Popp, A., Poulter, B., Riahi, K., Shevliakova, E., Stehfest, E., Thornton, P., Tubiello, F. N., Vuuren, D. P. van and Zhang, X.: Harmonization of Global Land-Use Change and Management for the Period 850\&ndash;2100 (LUH2) for CMIP6, Geoscientific Model Development Discussions, 1-65, doi:https://doi.org/10.5194/gmd-2019-360, 2020.

Ito, A. and Inatomi, M.: Water-Use Efficiency of the Terrestrial Biosphere: A Model Analysis Focusing on Interactions between the Global Carbon and Water Cycles, J. Hydrometeor., 13(2), 681-694, doi:10.1175/JHM-D-10-05034.1, 2011.

Ito, A. and Oikawa, T.: A simulation model of the carbon cycle in land ecosystems (Sim-CYCLE): a description based on dry-matter production theory and plot-scale validation, Ecological Modelling, 151(23), 143-176, doi:10.1016/S0304-3800(01)00473-2, 2002.

Krinner, G., Viovy, N., de Noblet-Ducoudré, N., Ogée, J., Polcher, J., Friedlingstein, P., Ciais, P., Sitch, S. and Prentice, I. C.: A dynamic global vegetation model for studies of the coupled atmosphere-biosphere system, Global Biogeochem. Cycles, 19(1), 33, 2005.

Lasslop, G., Thonicke, K. and Kloster, S.: SPITFIRE within the MPI Earth system model: Model development and evaluation, J. Adv. Model. Earth Syst., 6(3), 740-755, doi:10.1002/2013MS000284, 2014.

Lawrence, D. M., Fisher, R. A., Koven, C. D., Oleson, K. W., Swenson, S. C., Bonan, G., Collier, N., Ghimire, B., Kampenhout, L., Kennedy, D., Kluzek, E., Lawrence, P. J., Li, F., Li, H., Lombardozzi, D., Riley, W. J., Sacks, W. J., Shi, M., Vertenstein, M., Wieder, W. R., Xu, C., Ali, A. A., Badger, A. M., Bisht, G., Broeke, M., Brunke, M. A., Burns, S. P., Buzan, J., Clark, M., Craig, A., Dahlin, K., Drewniak, B., Fisher, J. B., Flanner, M., Fox, A. M., Gentine, P., Hoffman, F., Keppel-Aleks, G., Knox, R., Kumar, S., Lenaerts, J., Leung, L. R., Lipscomb, W. H., Lu, Y., Pandey, A., Pelletier, J. D., Perket, J., Randerson, J. T., Ricciuto, D. M., Sanderson, B. M., Slater, A., Subin, Z. M., Tang, J., Thomas, R. Q., Val Martin, M. and Zeng, X.: The Community Land Model Version 5: Description of New Features, Benchmarking, and Impact of Forcing Uncertainty, J. Adv. Model. Earth Syst., 11(12), 4245-4287, doi:10.1029/2018MS001583, 2019.

Li, F., Lawrence, D. M. and Bond-Lamberty, B.: Impact of fire on global land surface air temperature and energy budget for the 20th century due to changes within ecosystems, Environmental Research Letters, 12(4), 044014, doi:10.1088/1748-9326/aa6685, 2017.

Li, W., Zhang, Y., Shi, X., Zhou, W., Huang, A., Mu, M., Qiu, B. and Ji, J.: Development of Land Surface Model BCC_AVIM2.0 and Its Preliminary Performance in LS3MIP/CMIP6, J Meteorol Res, 33(5), 851869, doi:10.1007/s13351-019-9016-y, 2019.

Lindeskog, M., Arneth, A., Bondeau, A., Waha, K., Seaquist, J., Olin, S. and Smith, B.: Implications of accounting for land use in simulations of ecosystem carbon cycling in Africa, Earth System Dynamics, 4(2), 385-407, doi:10.5194/esd-4-385-2013, 2013. 
Mauritsen, T., Bader, J., Becker, T., Behrens, J., Bittner, M., Brokopf, R., Brovkin, V., Claussen, M., Crueger, T., Esch, M., Fast, I., Fiedler, S., Fläschner, D., Gayler, V., Giorgetta, M., Goll, D. S., Haak, H., Hagemann, S., Hedemann, C., Hohenegger, C., Ilyina, T., Jahns, T., Jimenéz-de-la-Cuesta, D., Jungclaus, J., Kleinen, T., Kloster, S., Kracher, D., Kinne, S., Kleberg, D., Lasslop, G., Kornblueh, L., Marotzke, J., Matei, D., Meraner, K., Mikolajewicz, U., Modali, K., Möbis, B., Müller, W. A., Nabel, J. E. M. S., Nam, C. C. W., Notz, D., Nyawira, S.-S., Paulsen, H., Peters, K., Pincus, R., Pohlmann, H., Pongratz, J., Popp, M., Raddatz, T. J., Rast, S., Redler, R., Reick, C. H., Rohrschneider, T., Schemann, V., Schmidt, H., Schnur, R., Schulzweida, U., Six, K. D., Stein, L., Stemmler, I., Stevens, B., Storch, J.-S. von, Tian, F., Voigt, A., Vrese, P., Wieners, K.-H., Wilkenskjeld, S., Winkler, A. and Roeckner, E.: Developments in the MPI-M Earth System Model version 1.2 (MPI-ESM1.2) and Its Response to Increasing CO2, Journal of Advances in Modeling Earth Systems, 11(4), 998-1038, doi:10.1029/2018MS001400, 2019.

Miller, P., Nieradzik, L. P., Wårlind, D., Smith, B., Lindeskog, M., Olin, S., Anthoni, P., Arneth, A., Dutra, E., Alessandri, A., Catalano, F., Wyser, K. and Tourigny, E.: Coupled dynamics of climate, vegetation, land use and terrestrial biogeochemistry in the EC-Earth-Veg ESM - implementation and evaluation, n.d.

Olin, S., Schurgers, G., Lindeskog, M., Wårlind, D., Smith, B., Bodin, P., Holmér, J. and Arneth, A.: Modelling the response of yields and tissue $\mathrm{C}: \mathrm{N}$ to changes in atmospheric $\mathrm{CO}_{2}$ and $\mathrm{N}$ management in the main wheat regions of western Europe, Biogeosciences, 12(8), 2489-2515, doi:10.5194/bg-12-2489$2015,2015$.

Parton, W. J., Stewart, J. W. B. and Cole, C. V.: Dynamics of C, N, P and S in grassland soils: a model, Biogeochemistry, 5(1), 109-131, doi:10.1007/BF02180320, 1988.

Peters, W., Velde, I. R. van der, Schaik, E. van, Miller, J. B., Ciais, P., Duarte, H. F., Laan-Luijkx, I. T. van der, Molen, M. K. van der, Scholze, M., Schaefer, K., Vidale, P. L., Verhoef, A., Wårlind, D., Zhu, D., Tans, P. P., Vaughn, B. and White, J. W. C.: Increased water-use efficiency and reduced CO 2 uptake by plants during droughts at a continental scale, Nature Geoscience, 11(10), 744-748, doi:10.1038/s41561018-0212-7, 2018.

Peylin, P.: The ORCHIDEE global land surface model: description and evaluation, n.d.

Piao, S., Sitch, S., Ciais, P., Friedlingstein, P., Peylin, P., Wang, X., Ahlström, A., Anav, A., Canadell, J. G., Cong, N., Huntingford, C., Jung, M., Levis, S., Levy, P. E., Li, J., Lin, X., Lomas, M. R., Lu, M., Luo, Y., Ma, Y., Myneni, R. B., Poulter, B., Sun, Z., Wang, T., Viovy, N., Zaehle, S. and Zeng, N.: Evaluation of terrestrial carbon cycle models for their response to climate variability and to $\mathrm{CO}_{2}$ trends, Global Change Biology, 19(7), 2117-2132, doi:10.1111/gcb.12187, 2013.

Robertson, E., Wiltshire, A. J. and Liddicoat, S.: A New Representation of Land-use in the JULES Land Surface Model, n.d.

Roehrig, R.: The CNRM global atmosphere model ARPEGE-Climat 6.3: description and evaluation, n.d.

de Rosnay, P., Polcher, J., Bruen, M. and Laval, K.: Impact of a physically based soil water flow and soilplant interaction representation for modeling large-scale land surface processes: PHYSICALLY BASED SOIL HYDROLOGY IN GCM, Journal of Geophysical Research: Atmospheres, 107(D11), ACL 3-1-ACL 3-19, doi:10.1029/2001JD000634, 2002.

Séférian, R., Nabat, P., Michou, M., Saint-Martin, D., Voldoire, A., Colin, J., Decharme, B., Delire, C., Berthet, S., Chevallier, M., Sénési, S., Franchisteguy, L., Vial, J., Mallet, M., Joetzjer, E., Geoffroy, O., Guérémy, J.-F., Moine, M.-P., Msadek, R., Ribes, A., Rocher, M., Roehrig, R., Salas-y-Mélia, D., Sanchez, 
E., Terray, L., Valcke, S., Waldman, R., Aumont, O., Bopp, L., Deshayes, J., Éthé, C. and Madec, G.: Evaluation of CNRM Earth System Model, CNRM-ESM2-1: Role of Earth System Processes in PresentDay and Future Climate, Journal of Advances in Modeling Earth Systems, 11(12), 4182-4227, doi:10.1029/2019MS001791, 2019.

Sellar, A. A., Jones, C. G., Mulcahy, J. P., Tang, Y., Yool, A., Wiltshire, A., O’Connor, F. M., Stringer, M., Hill, R., Palmieri, J., Woodward, S., Mora, L. de, Kuhlbrodt, T., Rumbold, S. T., Kelley, D. I., Ellis, R., Johnson, C. E., Walton, J., Abraham, N. L., Andrews, M. B., Andrews, T., Archibald, A. T., Berthou, S., Burke, E., Blockley, E., Carslaw, K., Dalvi, M., Edwards, J., Folberth, G. A., Gedney, N., Griffiths, P. T., Harper, A. B., Hendry, M. A., Hewitt, A. J., Johnson, B., Jones, A., Jones, C. D., Keeble, J., Liddicoat, S., Morgenstern, O., Parker, R. J., Predoi, V., Robertson, E., Siahaan, A., Smith, R. S., Swaminathan, R., Woodhouse, M. T., Zeng, G. and Zerroukat, M.: UKESM1: Description and Evaluation of the U.K. Earth System Model, Journal of Advances in Modeling Earth Systems, 11(12), 4513-4558, doi:10.1029/2019MS001739, 2019.

Sitch, S., Friedlingstein, P., Gruber, N., Jones, S. D., Murray-Tortarolo, G., Ahlström, A., Doney, S. C., Graven, H., Heinze, C., Huntingford, C., Levis, S., Levy, P. E., Lomas, M., Poulter, B., Viovy, N., Zaehle, S., Zeng, N., Arneth, A., Bonan, G., Bopp, L., Canadell, J. G., Chevallier, F., Ciais, P., Ellis, R., Gloor, M., Peylin, P., Piao, S. L., Le Quéré, C., Smith, B., Zhu, Z. and Myneni, R.: Recent trends and drivers of regional sources and sinks of carbon dioxide, Biogeosciences, 12(3), 653-679, doi:10.5194/bg-12-653$2015,2015$.

Smith, B., Wårlind, D., Arneth, A., Hickler, T., Leadley, P., Siltberg, J. and Zaehle, S.: Implications of incorporating $\mathrm{N}$ cycling and $\mathrm{N}$ limitations on primary production in an individual-based dynamic vegetation model, Biogeosciences, 11(7), 2027-2054, doi:10.5194/bg-11-2027-2014, 2014a.

Smith, M. J., Palmer, P. I., Purves, D. W., Vanderwel, M. C., Lyutsarev, V., Calderhead, B., Joppa, L. N., Bishop, C. M. and Emmott, S.: Changing how Earth System Modelling is done to provide more useful information for decision making, science and society., Bulletin of the American Meteorological Society, 140224132934008, doi:10.1175/BAMS-D-13-00080.1, 2014 b.

Swart, N. C., Cole, J. N. S., Kharin, V. V., Lazare, M., Scinocca, J. F., Gillett, N. P., Anstey, J., Arora, V., Christian, J. R., Hanna, S., Jiao, Y., Lee, W. G., Majaess, F., Saenko, O. A., Seiler, C., Seinen, C., Shao, A., Sigmond, M., Solheim, L., von Salzen, K., Yang, D. and Winter, B.: The Canadian Earth System Model version 5 (CanESM5.0.3), Geoscientific Model Development, 12(11), 4823-4873, doi:10.5194/gmd-124823-2019, 2019.

Takata, K., Emori, S. and Watanabe, T.: Development of the minimal advanced treatments of surface interaction and runoff, Global and Planetary Change, 38(1), 209-222, doi:10.1016/S0921-8181(03)000304, 2003.

Takemura, T., Okamoto, H., Maruyama, Y., Numaguti, A., Higurashi, A. and Nakajima, T.: Global threedimensional simulation of aerosol optical thickness distribution of various origins, Journal of Geophysical Research: Atmospheres, 105(D14), 17853-17873, doi:10.1029/2000JD900265, 2000.

Tatebe, H., Tanaka, Y., Komuro, Y. and Hasumi, H.: Impact of deep ocean mixing on the climatic mean state in the Southern Ocean, Sci Rep, 8(1), 1-9, doi:10.1038/s41598-018-32768-6, 2018.

Tatebe, H., Ogura, T., Nitta, T., Komuro, Y., Ogochi, K., Takemura, T., Sudo, K., Sekiguchi, M., Abe, M., Saito, F., Chikira, M., Watanabe, S., Mori, M., Hirota, N., Kawatani, Y., Mochizuki, T., Yoshimura, K., Takata, K., O\&amp;apos;ishi, R., Yamazaki, D., Suzuki, T., Kurogi, M., Kataoka, T., Watanabe, M. and 
Kimoto, M.: Description and basic evaluation of simulated mean state, internal variability, and climate sensitivity in MIROC6, Geoscientific Model Development, 12(7), 2727-2765, doi:10.5194/gmd-12-27272019, 2019.

Thonicke, K., Venevsky, S., Sitch, S. and Cramer, W.: The role of fire disturbance for global vegetation dynamics: coupling fire into a Dynamic Global Vegetation Model, Global Ecology and Biogeography, 10(6), 661-677, doi:10.1046/j.1466-822X.2001.00175.x, 2001.

Vancoppenolle, M., Fichefet, T., Goosse, H., Bouillon, S., Madec, G. and Maqueda, M. A. M.: Simulating the mass balance and salinity of Arctic and Antarctic sea ice. 1. Model description and validation, Ocean Modelling, 27(1-2), 33-53, doi:10.1016/j.ocemod.2008.10.005, 2009.

Wu, T., Li, W., Ji, J., Xin, X., Li, L., Wang, Z., Zhang, Y., Li, J., Zhang, F., Wei, M., Shi, X., Wu, F., Zhang, L., Chu, M., Jie, W., Liu, Y., Wang, F., Liu, X., Li, Q., Dong, M., Liang, X., Gao, Y. and Zhang, J.: Global carbon budgets simulated by the Beijing Climate Center Climate System Model for the last century, Journal of Geophysical Research: Atmospheres, 118(10), 4326-4347, doi:10.1002/jgrd.50320, 2013.

Wu, T., Lu, Y., Fang, Y., Xin, X., Li, L., Li, W., Jie, W., Zhang, J., Liu, Y., Zhang, L., Zhang, F., Zhang, Y., Wu, F., Li, J., Chu, M., Wang, Z., Shi, X., Liu, X., Wei, M., Huang, A., Zhang, Y. and Liu, X.: The Beijing Climate Center Climate System Model (BCC-CSM): the main progress from CMIP5 to CMIP6, Geoscientific Model Development, 12, 1573-1600, doi:10.5194/gmd-12-1573-2019, 2019.

Wyser, K., van Noije, T., Yang, S., von Hardenberg, J., O\&amp;apos;Donnell, D. and Döscher, R.: On the increased climate sensitivity in the EC-Earth model from CMIP5 to CMIP6, preprint, Climate and Earth System Modeling., 2019.

Wyser, K., Kjellström, E., Königk, T., Martins, H. and Doescher, R.: Warmer climate projections in ECEarth3-Veg: the role of changes in the greenhouse gas concentrations from CMIP5 to CMIP6, Environmental Research Letters, doi:10.1088/1748-9326/ab81c2, 2020.

Yin, X.: Responses of leaf nitrogen concentration and specific leaf area to atmospheric CO2 enrichment: a retrospective synthesis across 62 species, Global Change Biology, 8(7), 631-642, doi:10.1046/j.13652486.2002.00497.x, 2002.

Yool, A., Popova, E. E. and Anderson, T. R.: MEDUSA-2.0: an intermediate complexity biogeochemical model of the marine carbon cycle for climate change and ocean acidification studies, Geoscientific Model Development, 6(5), 1767-1811, doi:10.5194/gmd-6-1767-2013, 2013.

Zaehle, S., Medlyn, B. E., De Kauwe, M. G., Walker, A. P., Dietze, M. C., Hickler, T., Luo, Y., Wang, Y.P., El-Masri, B., Thornton, P., Jain, A., Wang, S., Warlind, D., Weng, E., Parton, W., Iversen, C. M., GalletBudynek, A., McCarthy, H., Finzi, A., Hanson, P. J., Prentice, I. C., Oren, R. and Norby, R. J.: Evaluation of 11 terrestrial carbon-nitrogen cycle models against observations from two temperate Free-Air $\mathrm{CO} 2$ Enrichment studies, New Phytol, 202(3), 803-822, doi:10.1111/nph.12697, 2014. 